\title{
Building a business case for implementation of circular economy in higher education institutions
}

DOI:

10.1016/j.jclepro.2019.02.045

\section{Document Version}

Accepted author manuscript

Link to publication record in Manchester Research Explorer

\section{Citation for published version (APA):}

Mendoza, J. M. F., Gallego-schmid, A., \& Azapagic, A. (2019). Building a business case for implementation of circular economy in higher education institutions. Journal of Cleaner Production.

https://doi.org/10.1016/j.jclepro.2019.02.045

\section{Published in:}

Journal of Cleaner Production

\section{Citing this paper}

Please note that where the full-text provided on Manchester Research Explorer is the Author Accepted Manuscript or Proof version this may differ from the final Published version. If citing, it is advised that you check and use the publisher's definitive version.

\section{General rights}

Copyright and moral rights for the publications made accessible in the Research Explorer are retained by the authors and/or other copyright owners and it is a condition of accessing publications that users recognise and abide by the legal requirements associated with these rights.

\section{Takedown policy}

If you believe that this document breaches copyright please refer to the University of Manchester's Takedown Procedures [http://man.ac.uk/04Y6Bo] or contact uml.scholarlycommunications@manchester.ac.uk providing relevant details, so we can investigate your claim.

\section{OPEN ACCESS}




\title{
Building a business case for implementation of circular economy in higher education institutions
}

\author{
Joan Manuel F. Mendoza*, Alejandro Gallego-Schmid and Adisa Azapagic
}

Sustainable Industrial Systems, School of Chemical Engineering and Analytical Science, The Mill, The University of Manchester, Sackville Street, M13 9PL Manchester, United Kingdom

*Corresponding author: joan.mendoza@manchester.ac.uk; joanmanuel.fm@gmail.com

\begin{abstract}
Various frameworks have been developed to guide organisations in embedding circular economy principles in their strategy and operational practice. However, there is a lack of studies analysing practical implementation of circular economy thinking in the higher education sector. Higher education institutions are strategic agents in supporting sustainable development through teaching, research and social outreach activities. They also represent a source of environmental impacts due to significant resource consumption and waste generation. This paper presents the first comprehensive study showing how higher education institutions can use an action-led step-by-step approach to build a business case and implement circular economy thinking in practice. The University of Manchester is used as an illustrative example of a large higher education institution. First, a background analysis and semi-structured interviews were carried out to determine the scope of the university's current sustainability policies and the ability of the management systems to respond to circular economy challenges. This was followed by stakeholder workshops to identify gaps and opportunities for building a business case for implementation of a circular economy. Finally, a critical assessment of the outcomes was carried out to identify further research needs for implementation of a circular economy in higher education institutions. Although focused on the higher education sector, the proposed action-led approach can be used by any organisation in the service sector looking to build more circular and sustainable business models.
\end{abstract}

Keywords: Backcasting; framework; resource efficiency; service sector; sustainable business model innovation; university.

\section{Introduction}

Shifting from the "take-make-consume-dispose" linear economic system towards a circular economy (CE) model, where materials and products are reused for the longest possible time in closed-loop systems, represents an instrumental strategy for sustainable development (Murray et al. 2017). CE strategies aim to slow and close resource loops (Kraaijenhagen et al. 2016). The former involves prolonging and intensifying the use of assets to retain their value over time (Bocken et al. 2016). Closing resource loops is aimed at post-consumer waste upcycling to restore or create new value from worn-out materials (McDonough and Braungart 2013). Worn-out materials can also be cascaded into different low-grade applications before they are recycled (Moreno et al. 2016), similar to the way natural systems cascade nutrients and energy (Pauli 2010; McDonough and Braungart 2002). All these CE strategies can be facilitated and/or reinforced through the development of eco-efficient solutions to narrowing resource flows (Bocken et al. 2017), which progressively reduce the resource intensity and ecological impacts per functional unit (WBCSD 2006). Thus, "CE" is an umbrella concept (Blomsma and Brennan 2017) that integrates a diverse range of complementary strategies to support sustainable resource management from a cradle-to-cradle perspective.

However, a system-level transformation of value chains is required to shift from today's linear production and consumption systems to a full CE model (EEA 2016). For instance, 
business-as-usual recycling (e.g. downcycling) and other marginal eco-efficiency improvements (e.g. a reduction in energy consumption) are not sufficient to drive the required fundamental change to facilitate the decoupling of socio-economic growth from resource consumption and environmental impacts (Kopnina 2018a). A truly circular and sustainable economy cannot be deployed by applying traditional economic reasoning based on continuous unsustainable growth (Rammelt and Crisp 2014). It calls for rethinking production processes, legislative frameworks and consumer needs and expectations (Kopnina 2018b).

Thus, the responsibility to facilitate the transition to a CE is shared by businesses, policymakers and citizens, where active cooperation between actors is imperative (Geissdoerfer et al. 2017). Nevertheless, businesses in particular play a central role in supporting the transition to a CE due to their greater ability, competencies and resources to drive change (Geissdoerfer et al. 2017). There is a growing consensus in among scientists and practitioners that business model innovations are a key pathway to supporting the systemic changes that the shift towards a circular and sustainable economy entails (Accenture 2015; Lieder and Rashid 2016; Antikainen and Valkokari 2016).

Business model innovations refer to the process of devising and realising a novel way of doing business beyond the individual redesign and optimisation of existing products and practices (Chesbrough 2007). It involves the implementation of new mechanisms to create, deliver and capture value in order to reconceptualise a firm's purpose, drive corporate transformation and enhance competitive advantage (Mitchell and Coles 2003; Osterwalder and Pigneur 2010; Amit and Zott 2012). Likewise, the holistic nature of business model innovations can facilitate the systematic implementation of CE principles into business operations to support the execution of ambitious corporate sustainability strategies (Schaltegger et al. 2012). Accordingly, a number of decision-support frameworks have been developed to guide organisations in building sustainable business models congruent with the CE principles (e.g. Lewandowski 2016; Witjes and Lozano 2016; Mendoza et al. 2017; BSI 2017). However, case studies demonstrating how CE frameworks can drive change within organisations from the service sector are scarce (Johannsdottir 2014; Heyes et al. 2018).

Higher Education Institutions (HEIs) represent an area of particular interest for CE implementation due to their socio-economic relevance for the service sector and their influential role in supporting sustainable development in cities and regions worldwide (Ferrer-Balas et al. 2008). HEls contribute to the economic progress and social wellbeing through knowledge creation and dissemination (research and teaching) and community development (outreach activities) (OECD 2010). However, all these activities generate different environmental impacts due to significant resource consumption and waste generation (Carbon Trust 2012; EAUC 2016). Thus, HEls should not be perceived only as sustainability drivers through teaching, research and social outreach activities but also as organisations that should apply CE principles in practice in order to lead by example (Stephens et al. 2008).

The analysis of barriers and opportunities to improve environmental performance of HEls through the implementation and operationalisation of sustainability management systems has been given much attention in the literature (e.g. Lozano et al. 2015a; Ramos et al. 2015; Kılkış 2017; Omrcen et al. 2018). However, little is known about practical application of CE thinking in HEls to improve sustainability management processes. As far as the authors are aware, there is only one study that analysed CE practices in HEls. The University of Edinburgh (2015) evaluated the implementation of CE thinking in curricula development, outreach activities and campus management. The findings revealed that the CE concept was not yet fully embedded within current campus 
operations due to an overall lack of awareness and understanding of the CE concept among staff, including conservative and rigid governance structures and operating models, insufficient policies, limited stakeholder collaboration and decision-support frameworks, as well as time and financial constraints.

One of the often-quoted reasons by organisations for not implementing a CE is the lack of evidence of its benefits and difficulties in building a business case (EEA 2016). In an attempt to facilitate the latter, this paper takes an action-led approach to help build a business case for CE implementation (and experimentation) in HEls. This includes the development of participatory workshops and the use of a novel tailor-made analytical toolbox able to support decision-making processes to drive organisational and operational changes. The University of Manchester is used as an illustrative case for these purposes. The focus is on the implementation of CE thinking to campus management. The implementation of CE principles in education and research is out of scope because it has already been addressed in the literature, as described in Mendoza et al. (2019). The next section describes the methodology used in the study, followed by the results in Section 3. A critical assessment of the research outcomes and limitations is provided in Section 4 and the conclusions are drawn in Section 5.

\section{Methodology}

This section describes step-by-step the analytical framework and toolbox applied in the University of Manchester (illustrative case study) to identify opportunities to implement CE business model innovations.

\subsection{Action-led CE assessment framework}

Action-led research is an iterative and flexible approach that brings richness to case studies through stakeholder engagement (Robson and McCartan 2016; Bryman and Bell 2015). It also requires researchers to take a participating role through a cyclical process of intervention and reflection to negotiate solutions considering multiple perspectives and interests of stakeholders with different powers and resources (Somekh 2006; Herr and Anderson 2005). As a result, knowledge and practical solutions can be built simultaneously, making the research outcomes more reliable and applicable in real life (Baldassarre et al. 2017).

The action-led Backcasting and Eco-design for Circular Economy (BECE) framework (Mendoza et al. 2017) was used here as guidance to identify intervention areas and evaluate opportunities for development of innovative CE business models for HEls. As the name would suggest, BECE integrates backcasting and eco-design approaches. Backcasting is a system-level business planning tool used to support the development of action plans for achieving a long-term future vision by looking backwards from the desired future goal or situation (Vergragt and Quist 2011). It is useful for strategic alignment of CE business model innovations with viable development pathways for building successful sustainable business models (Mendoza et al. 2017). Eco-design is an operational-level tool for systematic integration of life cycle environmental considerations into the development of sustainable products, services and systems (Crul and Diehl 2009). Whereas backcasting is crucial for informing eco-design processes from the top down, eco-design is critical for supporting sustainable business model innovations from the bottom up (Mendoza et al. 2017). This bridges the gap between the strategic and operational levels, which is key for a successful realisation of the CE concept (Pomponi and Moncaster 2017; Winans et al. 2017).

The BECE framework (Mendoza et al. 2017) can be applied in three stages: exploration, assessment and reflection. As illustrated in Figure 1, exploration consists of two steps: 1) background analysis to gather baseline information and determine the scope of sustainability policies and practices developed by the focal organisation and 2) 
stakeholder engagement through interviews to obtain a buy-in and learn about the effectiveness of the organisation's sustainability management systems. As a result, the level of implementation of CE thinking by an organisation can be determined, including the identification of gaps and high-level opportunities for improvement.

The assessment stage entails the development of two participatory workshops to analyse gaps and opportunities and help make first steps towards building a business case for the implementation of CE. The first workshop (gaps analysis) involves the development of two research activities, where backcasting thinking is implemented:

- envisioning a CE business model by building an overarching CE vision coherent with the organisation's core priorities and analysing the associated drivers and constraints; and

- analysing the circularity and sustainability performance of the current business model to identify gaps and opportunities for achieving the CE vision.

The second workshop (opportunity assessment) is aimed at the development of two additional activities, where eco-design thinking is applied:

- designing alternative CE business models through idea generation, evaluation and prioritisation; and

- implementing CE business model innovations through the development of strategic pathways, roadmaps and action plans for the execution of feasible solutions.

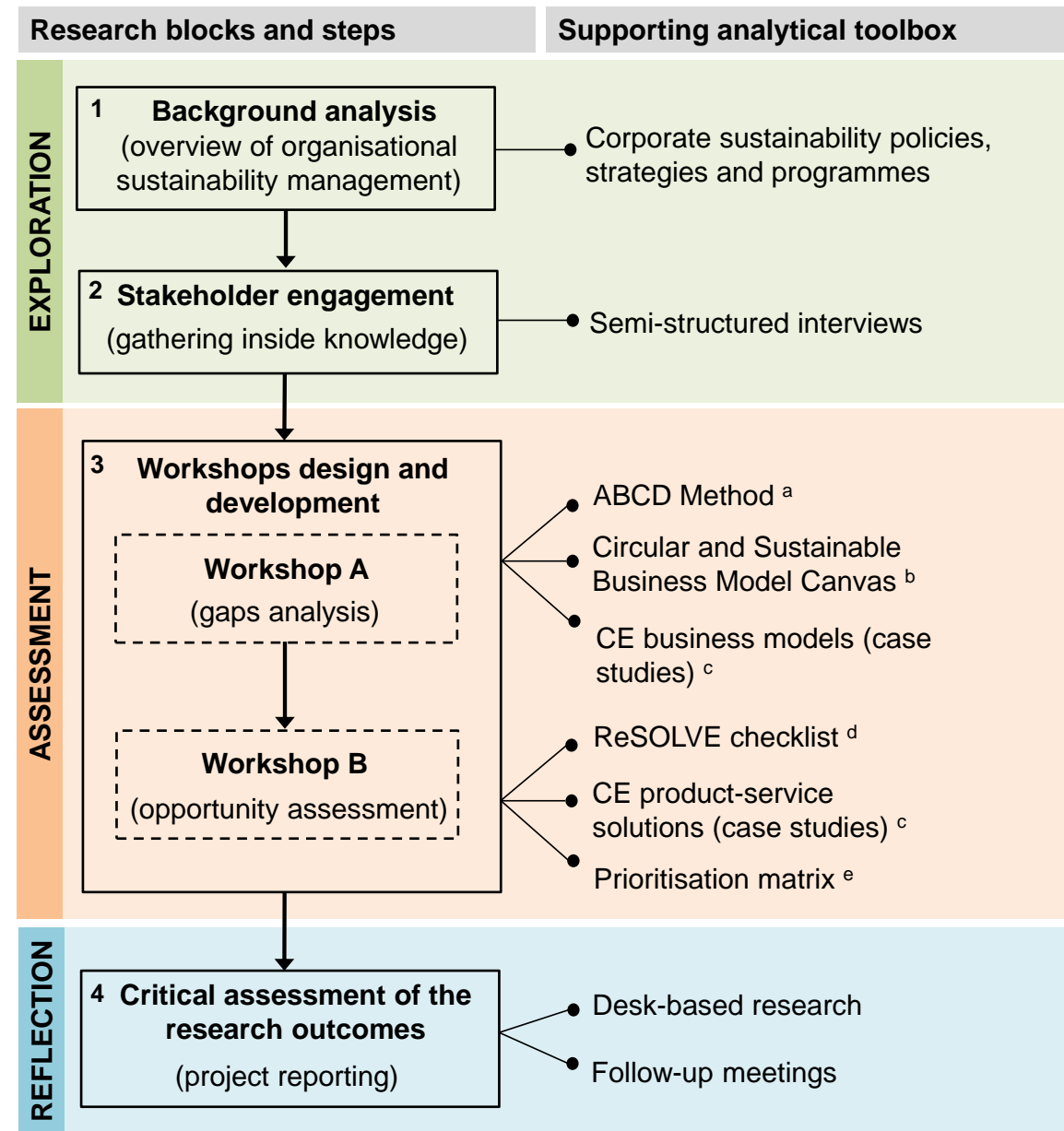

Figure 1 Action-led research methodology to build business case for implementation of circular economy [ ${ }^{\mathrm{a}}$ Broman and Robèrt $(2017) ;{ }^{\mathrm{b}}$ Design adapted from Osterwalder and Pigneur (2010) and Bocken et al. (2018); ' See Table 2; ${ }^{d}$ EMF (2015), e Design adapted from Crul and Diehl (2009). CE: Circular economy]. 
Finally, the reflection stage comprises the critical assessment of the information and data obtained in the previous two stages, with the purpose of driving institutional change and implementing a CE strategy.

The flexibility of the BECE framework (Mendoza et al. 2017) also facilitates the selection and customisation of different analytical tools for use in a modular fashion to support decision-making processes (Figure 1). Accordingly, BECE-related analytical toolboxes are not predetermined but they are tailored for specific cases as needed. This is described further in the following sections.

\subsection{Application of the CE assessment framework to the University of Manchester}

Case study-based exploration has become one of the most common and important approaches for supporting sustainability research (Hoover and Harder 2015). This is due to its suitability for analysing novel and complex phenomena with multiple relationships and unclear boundaries. Well-documented case studies offer meaningful insights and rich data for understanding organisational and operational processes, facilitating sustainability-based decision-making (Barth and Thomas 2012). Furthermore, case studies are particularly useful for critical analysis of existing theory as well as understanding rare, unique or emerging events where there is little knowledge available about a complex phenomenon under assessment (Yin 2003). This applies to the development of CE business models by HEls.

The University of Manchester has over 40,000 undergraduate and postgraduate students from 160 different countries and employs more than 12,000 staff. Thus, it is the UK's most international university (biggest student community in the UK) and one of the largest employers in Greater Manchester (annual income $>£ 1$ billion). The University of Manchester is also the largest single-site university in the UK, with 229 buildings scattered in an area of 270 hectares, and it currently has on one of the largest 10-year capital investment programmes ( $£ 1.75$ billion) in UK higher education to create a worldclass campus (UoM 2018). According to the 2018 Academic Ranking of World Universities, Manchester was ranked the $34^{\text {th }}$ in the world, $8^{\text {th }}$ in Europe and $6^{\text {th }}$ in the UK. It was also ranked the $80^{\text {th }}$ in the world, $7^{\text {th }}$ in Europe and $3^{\text {rd }}$ in the UK in the 2018 Reuters Top 100 Most Innovative Universities (UoM 2018).

Nevertheless, the University of Manchester is also a major consumer of resources and contributor to environmental impacts due to various activities across the campus. For instance, the university consumes almost 247 GWh of energy annually, emitting around $72,000 \mathrm{t}$ of greenhouse gases (GHG). The latter is equivalent to annual GHG emissions of over 36,100 average EU households. The organisation also consumes over 740 million litres of water annually, which is equivalent to 280 Olympic swimming pools. Furthermore, $7000 \mathrm{t}$ of waste is produced, of which only $30 \%$ is usually recycled (Mendoza et al. 2019). Consequently, it is important to rethink university's processes, operations and strategies in order to improve the resource efficiency and environmental performance of the organisation.

The following subsections describe how the action-led research methodology in Figure 1 was applied to the case of the University of Manchester to help identify, assess and prioritise strategic actions for building a business case for implementation of a CE.

\subsubsection{Exploration}

The background analysis (step 1, Figure 1) entailed the assessment of the scope of the most relevant corporate sustainability policies, strategies and action plans, including Manchester 2020 Strategic Plan (UoM 2015), Campus Masterplan 2012-2022 (UoM 2012), Environmental Sustainability Strategy (UoM 2016), Sustainable Resources Plan (UoM 2017a) and Living Campus Plan (UoM 2017b). The so-called "Stocktake Reports" 
(UoM 2017c) were also evaluated to gather relevant information on the university's performance. These annual reports provide a detailed appraisal of progress against the corporate goals, enabling strategies and key performance indicators of the University's 2020 Strategic Plan, and are a key component of the organisation's planning and accountability cycle.

Subsequently, a team of 12 sustainability-oriented academics and technical staff was engaged to participate in individual semi-structured interviews to get inside knowledge of the effectiveness of the mechanisms (frameworks, tools and key performance indicators) used within the organisation for development and monitoring of sustainability strategies (step 2, Figure 1). The team included experts with different roles and responsibilities along the governance structure, who were able to drive change within the organisation. Most of the participants belonged to the university's environmental sustainability team, which leads the development, implementation and monitoring of the university's Environmental Sustainability Strategy (UoM 2016) and the related Action Plans (UoM 2017a, 2017b). Thus, participants were usually involved in regular sustainability-based decision-making processes within the organisation. Consequently, this sample was considered appropriate for obtaining multiple perspectives and enriching the dialogue on the challenges and opportunities related to CE implementation in the university. Further information on the stakeholder roles and the interview questions can be found in Table S1 and Section S1 in the Supporting Information (SI). The outcomes from the background analysis and interviews are presented in Section 3.1.

\subsubsection{Assessment}

Two participatory workshops (step 3, Figure 1) were held shortly after the interviews were completed. Prior to the development of the workshops, the facilitators (two first authors of this paper) sent to the participants the workshops programmes with a brief description of their purpose and practical activities (Section S2 in the $\mathrm{SI}$ ). For consistency, the workshop participants were those previously interviewed.

Each workshop lasted four hours to avoid information overload and minimise interruption to the stakeholders' daily activities (Heyes et al. 2018). Some time for analysis and preparation by the facilitators was necessary between the workshops because the outcomes from workshop A (gaps analysis) influence the scope of workshop B (opportunity assessment). Relevant findings from the group discussions were captured by detailed note-taking, including direct sketching on flip-charts that were later digitalised for research purposes (step 4, Figure 1). Once the workshops ended, a group discussion was held to summarise outcomes and get feedback on the usefulness of the workshops' setting and the analytical toolbox employed. The outputs from the workshops can be found in Sections 3.2 and 3.3.

\subsubsection{Workshop A - gaps analysis}

An introductory session provided an overview of the CE concept and its key principles (EMF 2015). This was aimed at facilitating a better understanding of the full scope of a $\mathrm{CE}$ and encouraging participants to start applying CE thinking. The ABCD method (Broman and Robèrt 2017) was used to explain the backcasting-related tasks to be developed in the workshop. The ABCD method is a simple operational procedure for pragmatic co-creation of strategies towards sustainability. It consists of four basic steps - awareness and visioning, baseline assessment, creative solutions, devising a plan which are repeated continuously as an organisation progresses towards sustainability (Broman and Robèrt 2017). Participants were encouraged to be open-minded and think 'out of the box' to move away from incremental sustainability practices towards more radical solutions. 
The first group activity of workshop A involved co-creating an overarching vision compliant with the CE principles and coherent with the organisation's core goals and priorities. Afterwards, participants were asked to identify the drivers and constraints for the adoption of a CE-compliant vision by considering the gap between the future desired state and the current reality of the university. This was useful for identifying a number of relevant barriers and challenges that need to be overcome for the implementation of a $\mathrm{CE}$ across the campus. Likewise, a number of existing assets that can help the organisation to move forward, including opportunities for further exploration, were identified. The outcomes from these activities are presented in Section 3.2.1.

The second part of workshop A involved an analysis of the circularity and sustainability performance of the university's current business model. The Business Model Canvas (BMC) (Osterwalder and Pigneur 2010) was used for this purpose. BMC is a strategic management tool that facilitates structured analysis of a business model. It reflects the logic of strategic thinking about value, which can be divided into (Richardson 2008; Boons and Lüdeke-Freund 2013):

- value proposition: superior product and service offering to solve a problem or satisfy a need;

- value creation/supply chain: resources, activities, processes and partners required to create and deliver value to customers;

- value delivery/customer interface: downstream logistics and business activities to engage and deliver value to customers; and

- value capture/financial model: instruments and mechanisms to deal with costs and generate profits.

Accordingly, the BMC supports the identification of opportunities for implementing business model innovations, including strategy reorientation, formulation of entirely new business concepts and development of novel product-service solutions (Strategizer 2015; Joyce and Paquin 2016; França et al. 2017).

However, the BMC is not able to support sustainability-oriented choices because it is economically-driven for profit generation (Joyce and Paquin 2016; Upward and Jones 2016). Therefore, a Circular and Sustainable Business Model Canvas (CSBMC) was developed for use in the workshop to get an overview of the university's baseline circularity and sustainability performance (see Section 3.1.2.). Building on EMF (2017) and Tiemann and Fichter (2016), a set of CE- and sustainability-related questions were posed to the participants, along with the classic list of economics-oriented questions proposed by Osterwalder and Pigneur (2010), to populate each building block of the canvas. Handouts, provided in section S3 in the SI, were shared with the participants, including a brief description of each building block of the CSBMC and the related set of questions. The participants were asked to apply a user-centred approach to populate the canvas by starting with the identification of the main customers and the analysis of the value propositions delivered to them. The results of these activities are discussed in Section 3.2.2.

\subsubsection{Workshop B - opportunity assessment}

The ReSOLVE checklist (EMF 2015) was used in combination with the CSBMC to structure the analysis and prioritise potential CE innovations. This checklist consists of six strategic actions: regenerate, share, optimise, loop, virtualise and exchange. They all follow the CE principles of preserving and enhancing natural capital, optimising resource yields and designing out negative externalities (EMF 2015).

According to the EMF (2015), the greatest CE potential for universities lies in the implementation of three key actions: virtualise, share and optimise. Therefore, only these ReSOLVE actions were considered in the analysis. Virtualise entails displacing resource 
consumption by delivering utilities virtually (e.g. deliver products as services, accessing performance, functionality or capability). Share denotes maximising products and assets utilisation by promoting reuse, maintenance and sharing activities among different users (e.g. peer-to-peer sharing, co-location and second-hand markets). Optimise involves increasing system efficiency and performance by keeping materials and components at their highest value over time, reducing resource consumption per product/service unit and eliminating waste generation in supply chains.

A set of inspirational case studies from other organisations (outside the HE sector) were collected and grouped into the virtualise, share and optimise ReSOLVE actions. The case studies were gathered from different databases, including the EMF (2017a), Circle Economy (2017) and Arup (2016), as well as from business websites. The selected case studies are listed in Section 3.3.1. They were useful to demonstrate how organisations are approaching and developing CE actions through business model and productservice innovation. This activity was also valuable for encouraging creative thinking, open dialogue, idea exchange and facilitating the selection and prioritisation of CE actions. The outcomes are presented in Section 3.3.1.

Building on Crul and Diehl (2009), an opportunity prioritisation matrix was used to prioritise the implementation of virtualise, share and optimise CE business model innovations based on their technical, socio-economic and environmental feasibility and potential overall benefits for the university. Participants were asked to classify strategies into four categories as shown in Figure 2. As a result, an action plan for the development of a business case for CE implementation was developed. This can be found in Section 3.3.2.

Although university's relevant customers (students, government, etc.) were not directly engaged in the development of the workshops, the university staff (participants) based their analysis on their knowledge and feedback over the years from the customers to monitor the efficiency and effectiveness of the Manchester 2020 Strategy and the related action plans.

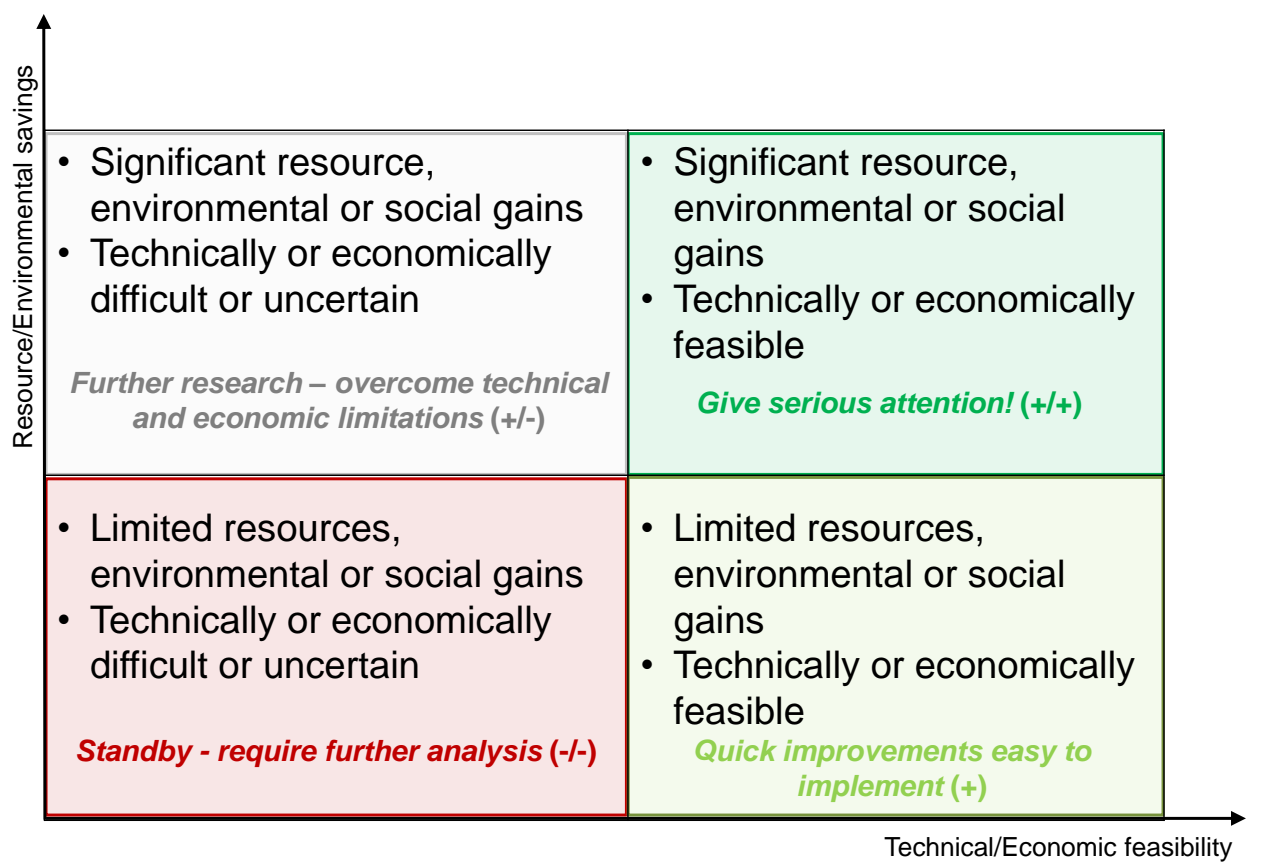

Figure 2 CE-opportunity prioritisation matrix (adapted from Crul and Diehl 2009). 


\subsubsection{Reflection}

The information and data generated during the development of the exploratory (Section 2.2.1) and assessment (Section 2.2.2) stages were critically analysed and validated from an integrated perspective (step 4, Figure 1). This resulted in the development of a synthesis report shared with the university key stakeholders, including guidelines and recommendations to drive organisational and operational change and embed CE principles within the university's core goals, priorities and sustainability policies.

A number of follow-up meetings were held to guide the university's environmental sustainability team in implementing measures that support the goals and targets set in the Sustainable Resources Plan (UoM 2017). As a result, guidelines for HEls on how to build a business case for implementation of a CE were proposed (Section 4). Prior to that, the following section details the results of applying the BECE framework described above.

\section{Results}

This section presents the key findings from the background analysis, stakeholder interviews and participatory workshops. The outcomes from the reflection stage are presented in Section 4.

\subsection{Background analysis and stakeholder interviews}

The environmental sustainability strategies implemented by the University of Manchester (UoM 2016, 2017a,b) incorporate a number of CE criteria, which can be reinforced and extended further to improve organisational sustainability.

Although there is no explicit mention of the CE concept in any of the corporate sustainability policies, the organisation is unconsciously applying CE thinking in certain activity areas. Examples include the marketplace online platform for the reuse of secondhand products by staff, the university furniture and IT reuse centres to redistribute products across the campus, trayless dining areas in catering halls, IT services virtualisation, provision of reusable mugs to students, implementation of recycling facilities across the campus and green coverage of the built environment (UoM 2017a,b). These strategies contribute mostly to prolong and intensify the use of products and facilitate post-consumer waste recycling, which are key requirements to support a CE. They help to preserve natural capital, optimise resource yields and reduce negative externalities (EMF 2015).

However, the stakeholder interviews demonstrated that the university's environmental sustainability policies have been developed without incorporating CE thinking explicitly due to the lack of understanding of the practical application of the concept in the university context. The stakeholders also highlighted a lack of leadership teams, competences allocation, suppliers' engagement and effective policies targeting CE as an instrumental pathway to achieving long-term organisational sustainability. Another relevant challenge to facilitate CE implementation in the university includes the lack of access to appropriate decision-support frameworks, data gathering systems and key performance indicators.

As a result, there are no initiatives and practices yet implemented, which fully reflect the CE concept; those that do exist are limited in scope. For instance, most of the environmental sustainability strategies are aimed at improving resource efficiency (e.g. by reducing energy consumption and waste generation) in order to reduce carbon emissions, rather than rethinking current unsustainable processes and narrow corporate strategies. None of the university's environmental sustainability initiatives has the capacity to motivate radical improvements in organisational sustainability performance if 
they are not accompanied by strategic changes in the current business model (Mendoza et al. 2017).

\subsection{Workshop A - gaps analysis}

\subsubsection{Overarching corporate CE vision, drivers and barriers}

As described in Section 2.2.2.1, the workshop participants were asked to co-create and agree a shared CE overarching vision that is practical, compelling and strategic for the university. The participants agreed on the need to build a vision that would allow the organisation to start taking simple and incremental steps ('low hanging fruit') rather than implementing more radical and disruptive changes. Thus, they suggested adapting slightly the definition of the CE concept provided by the EMF (2015) as a preliminary vision that would guide the university's journey towards a CE:

"A restorative and regenerative university by design that aims to keep products, components, and materials at their highest utility and value at all times."

It is important to highlight that when participants were asked in the interviews to describe what they understood as a CE, they were referring to the EMF's definition. This is because they were aware of it and it meant something to them (Mendoza et al. 2019). Thus, rather than propose a more sophisticated (and perhaps more complex to understand) definition of a $\mathrm{CE}$, and also given that the concept is still evolving and there is no consensus on its definition yet, the EMF-based CE vision proposed by the participants was considered appropriate for initiating the dialogue and encouraging critical thinking about it.

In order to facilitate a group discussion about the alignment of this vision with the corporate sustainability goals and its suitability to drive change within the organisation, the following questions were posed (EMF 2017b):

- What does success look like around this vision?

- What are we looking to accomplish?

- What impact do we want to have?

- What are the potential benefits?

- How will we know when we get there (evaluation/success criteria)?

These questions allowed participants to start defining what the business model of the university would look like in a future $\mathrm{CE}$, including the identification of drivers, barriers and opportunities, as shown in Table 1.

The analysis of the internal and external CE drivers and barriers, provided in Section S3 in the SI, led to the recognition of relevant opportunities for the university (Table 1). The workshop participants agreed that improving resource efficiency through the implementation of CE strategies across the university could reduce costs, life cycle carbon emissions and material consumption as well as encouraging creative thinking and innovation, improving educational programmes, motivating behavioural change among students and staff and facilitating community and stakeholder involvement in sustainability practice. Accordingly, implementation of a CE can help to achieve the university's social responsibility goals (see section 3.1.2.) set in the "10,000 Actions" programme (UoM 2017d). 
Table 1 Drivers, barriers and opportunities for CE implementation in the University of Manchester, as identified by the workshop participants.

\begin{tabular}{lll}
\hline Drivers & Barriers & Opportunities \\
\hline People & Money & Creative thinking \\
Work force & Ignorance & Regional consortium \\
Students & People & Education \\
Researchers & Time & Innovation \\
Legislation & Students expectations & Social responsibility goals \\
The region of Greater Manchester & Infrastructure and space & Lead by example as university \\
Tyndall Research Centre support & Business priorities & Period of change \\
Local suppliers & Ownership mind-set & Cost reduction \\
Location of the university & Low efficiency and space utilisation & 10,000 Actions programme \\
Freeholders of buildings and space & Conservative culture & Material circularity \\
Case studies & Seasonal changes in operations & Carbon emissions \\
Furniture for reuse programme & Building design and design regulations & Increase resilience \\
Building stock & Conservative approaches for decision- & Space management for students \\
& making & \\
Campus expansion & Higher Education Funding Council for & Community involvement \\
City evolution & England & Influence behaviour \\
Social responsibility goals & Finding the right waste solutions & \\
Partners & Incentives and risks & \\
& Misunderstanding about materials and & \\
\hline
\end{tabular}

The workshop participants also stressed that implementation of a CE can increase organisational resilience, defined as "the ability of an organisation to anticipate, prepare for, respond and adapt to incremental change and sudden disruptions in order to survive and prosper" (BSI 2015). Although there are relevant barriers to overcome (Section S3 in the SI), participants were aware of the potential benefits a CE can bring to the university.

\subsubsection{Business model circularity and sustainability performance}

FFigure 3 provides an overview of how the university creates, delivers and captures value, as described by the workshop participants and completed by the facilitators through multiple iterations and feedback loops. These are discussed in the next sections.

\subsubsection{Value proposition}

The main value propositions of the university are (UoM 2015):

1) develop world-class research (produce work of the highest significance and impact);

2) provide an outstanding teaching and student experience (graduates distinguished by their intellectual capabilities, employability, leadership and ability to contribute to society); and

3) excel in social responsibility (enhance the well-being and environmental performance of local communities and the wider society).

Social responsibility is embedded into research, teaching, extra-curricular activities and campus management. Likewise, the university has developed and implemented seven signature programmes to address relevant social challenges concerning sustainability, social justice and equity, workplace ethics, cultural entitlement and ring-fenced access to training, advice and job opportunities (UoM 2017e). Pursuing environmental sustainability is also integrated within the social responsibility value proposition, as described in the Manchester 2020 Strategic Plan and the Environmental Sustainability Strategy (UoM 2015, 2016). These documents describe in detail the core business goals and strategic priorities, including high-level key performance indicators (KPIs) and targets to measure performance and monitor progress on sustainability.

Thus, the university is committed to economic, social and environmental sustainability. Nevertheless, the CE concept and its principles are not embedded within the core value 
propositions due to a lack of understanding of its practical application. Thus, it is essential to define CE value propositions to ensure the application of CE thinking in the way the university creates, delivers and captures value.

\subsubsection{Value creation}

University operations, including teaching, research, campus management and outreach activities, consume a significant amount of resources that lead to various environmental impacts, as shown in Figure 3. Consequently, the Sustainable Resources Plan (UoM 2017a) and the Living Campus Plan (UoM 2017b) set targets and actions for reducing resource consumption and environmental impacts through appropriate estates management. Key activities to enhance the campus environmental sustainability include energy, water and waste management, encouragement of sustainable travel, development of green technical spaces, sustainable construction, responsible purchasing, sustainable catering and green infrastructure deployment (UoM 2017a).

The "10,000 Actions" signature programme was launched to facilitate the operationalisation of these action plans by providing all $10,000+$ staff members the opportunity to engage in sustainable resource management (UoM 2017d). Indeed, there are some initiatives in place with links to the CE concept, including:

- market-place online platform to share second-hand products, furniture and IT equipment;

- trayless dining areas to reduce waste generation;

- virtualisation of services to optimise energy efficiency;

- reusable coffee/tea mugs and packaging to support sustainable food consumption;

- waste recycling facilities; and

- green coverage to protect and enhance biodiversity across the campus.

These activities can be extended further to make the CE mainstream and improve the organisation's sustainability performance. However, workshop participants stressed that it was essential first to build a credible, practical and meaningful business case showing the benefits that the university could achieve by "going fully circular". This includes an analysis of the return on investments and measures to overcome risks. Getting access to this information is important to obtain a buy-in from university senior managers.

For instance, accessing light as a service (pay-per-lux, see Table 2) rather than purchasing lighting equipment and electricity was perceived as an interesting CE strategy for implementation across the campus. This strategy would help to improve energy efficiency and reduce electrical waste, also reducing costs and environmental impacts. However, this entails changing radically procurement mechanisms and campus management policies and operations. Likewise, this CE strategy could affect jobs of the university technical staff through a cut in the number of employees due to lower maintenance needs. There is also a need to enhance the current stakeholder network and engage new suppliers and partners, to drive effective changes towards CE. Additionally, the market readiness (e.g. suppliers and waste managers) to offer CE solutions suitable for the university is another major need and challenge. 


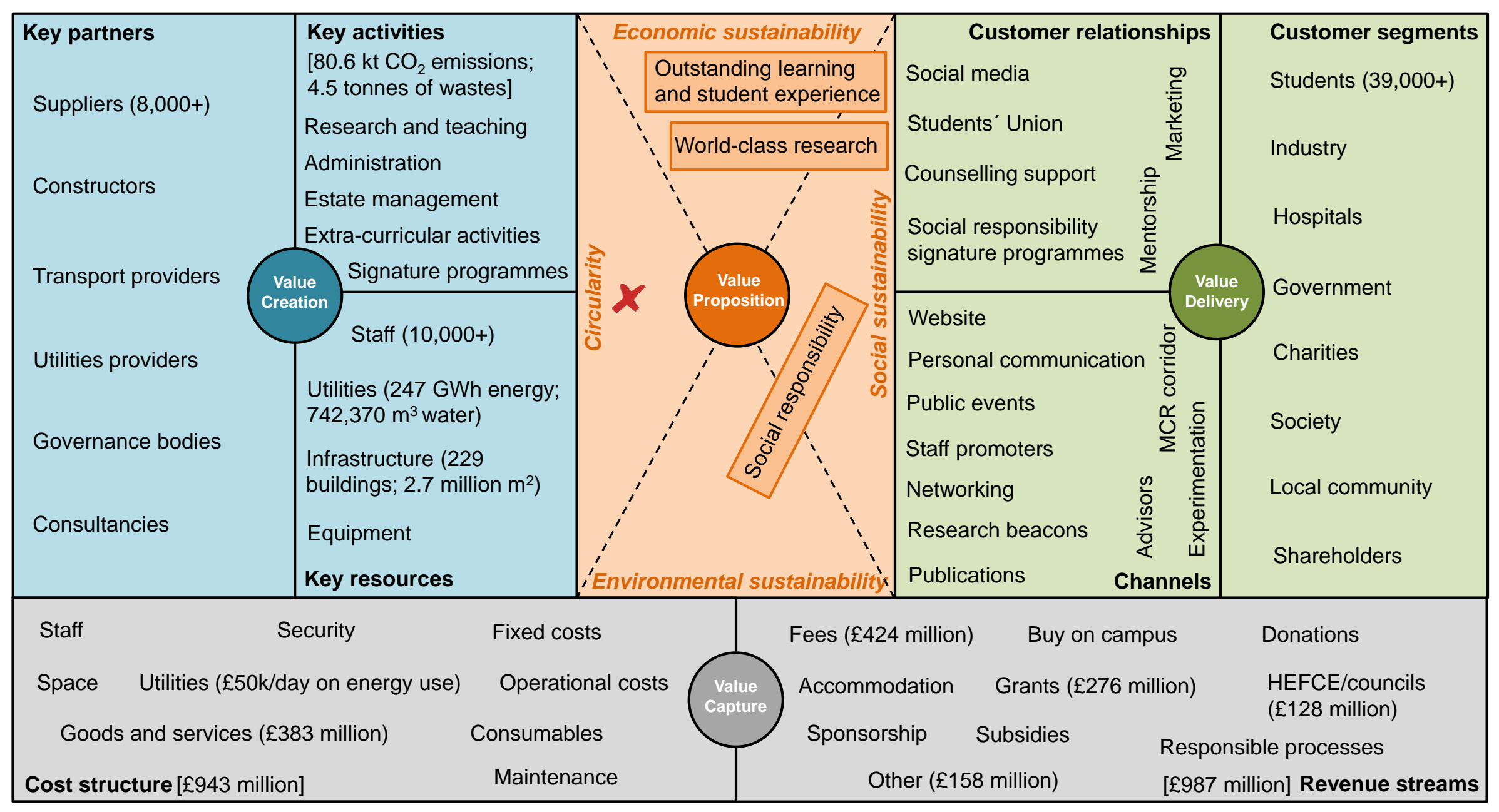

Figure 3 Results from the CSBMC mapping to provide an overview of the circularity and sustainability performance of the business model of the University of Manchester (template design adapted from Osterwalder and Pigneur 2010 and Bocken et al. 2018). [CSBMC - Circular and Sustainable Business Model Canvas; HEFCE - Higher Education Funding Council for England; MCR - Manchester]. 


\subsubsection{Value delivery}

The university delivers value to a large and diverse network of stakeholders (Figure 3), including society and the environment (value proposition 3 ). There are several bidirectional channels available to reach and engage customers segments. These channels could be classified into passive (e.g. website and publications) and active (e.g. public events, research beacons, staff promoters, advisors and experimentation). The university has also relevant sustainability engagement mechanisms, including green impact teams, sustainability champions and living labs, which can be used to raise awareness, experiment and motivate behavioural change towards a CE. This diversity of channels is important to ensure that different customers are reached in different ways in order to build bi-directional feedback loops able to guide the creation of novel CEoriented services (EMF 2017b).

According to the workshop participants, students are the most relevant customer segment (Figure 3). Thus, most of the customer relationships encountered by the participants are aimed at ensuring that the organisation meets students' needs and expectations. However, they also apply to other relevant customers, such as the industry, (teaching) hospitals and the government. These customer relationships can be divided into personal - direct interaction (e.g. tutoring, counselling support and mentorship) and impersonal services (e.g. social media and marketing). The university can therefore use these various channels to enhance stakeholder engagement process in CE management.

The participants highlighted that creating the conditions and the demand for a "circular" and sustainable use of the campus (buildings, facilities and space) can be crucial for driving a shift in the awareness, consumption patterns and expectations from students and staff. Sending feedback forms through the use of social media represents a simple, quick and cost-effective solution for collecting information that could be used later on for development of personalised and collective user-centric CE engagement strategies. For instance, building an automated system for gathering and sharing data related to campus management represents a promising strategy for establishing a strong relationship with students and developing CE studies on campus as part of their learning about social responsibility. To be meaningful, campus management data should be disaggregated by key operational areas (e.g. catering, accommodation, labs, offices, travel) and resource flows (e.g. energy, water, materials and wastes) should be allocated to buildings and facilities.

\subsubsection{Value capture}

Figure 3 shows the most significant costs incurred while operating under the current business model as well as the revenue streams the organisation generates from different sources and customer segments. Detailed information about the positive socio-economic impacts of the university can be found in the report "Measuring the Difference" (UoM 2017f).

The university uses the so-called NETpositive Supplier Engagement Tool (NETpositive Futures 2017) to engage suppliers in sustainability practice. However, this tool does not integrate CE criteria to guide sustainable procurement. For instance, the university does not encourage (as a priority rule) services over product purchasing to dematerialise campus operations. Staff can decide on purchases based on individual preferences. Thus, it is important for the organisation to start integrating CE criteria in responsible procurement processes to ensure that purchases will maximise organisational resource efficiency while minimising environmental impacts. 
All the workshop participants agreed that the development of a corporate CE procurement strategy could reduce costs of maintenance, waste management, energy and carbon emission tax. A share of the savings could be used to set up a new "CE signature programme" that could be embedded within the ongoing social responsibility activities or represent an independent but interrelated institutional action plan to support sustainable resource management. Such CE programme could motivate students and staff to co-create innovative solutions for more sustainable management of campus operations.

However, it is essential first to evaluate carefully the potential costs for the university as well as determining how a CE strategy could be set up to secure support from the funding councils, such as HEFCE (Figure 3). In this process, it is also important to determine the potential consequences of unforeseen issues, for example, losing staff by "going circular" due to lower maintenance requirements. A cost-benefit analysis should also be carried out to compare alternative scenarios and pathways, such as using services versus buying circular products.

The CSBMC mapping demonstrated a large potential for development of a range of CEoriented business model innovations within the university to enhance organisational resource efficiency and sustainability performance, as discussed further in the next section.

\subsection{Workshop B - opportunity assessment}

This workshop was developed to evaluate and prioritise strategic pathways and actions for implementation of CE business model innovations by the university. In order to facilitate and structure this analysis, a number of inspiring case studies were presented to the participants. The ReSOLVE checklist (EMF 2015) was used to group the case studies into key CE actions that can trigger the development of business model innovations (Section 2.2.2.2).

According to the participants, and the information in the Manchester 2020 Strategic Plan (UoM 2015) and the Stocktake Reports (UoM 2017c), the University of Manchester has set the target to achieve at least $90 \%$ student satisfaction in the National Student Survey by 2020 . This target relates to the value proposition of "delivering outstanding learning and student experience" (Section 3.2.2.1). Based on the information presented in Section 3.2.2.3, students represent the most relevant customer segment for the university. Thus, although students did not participate in this workshop, most of the CE solutions explored by the university staff were aimed at ensuring that the organisation meets students' needs and expectations, while improving resource efficiency and sustainability performance. Accordingly, the university staff evaluated different CE solutions based on their knowledge and student feedbacks over the years, including the University of Manchester Students' Union.

\subsubsection{Evaluation of CE business model innovations}

Table 2 provides a summary of opportunities and challenges for the application of virtualise, share and optimise CE actions, as perceived by the workshop participants. A more detailed description and analysis of the case studies is provided in Table S2 in the SI.

\subsubsection{Virtualise business model innovations}

Rather than purchasing products, the university can choose all-inclusive leasing contracts based on "pay-per-use" (Table 2). This approach could be used for lighting, office equipment and buildings. For example, sensor networks could be integrated to make use of the "internet of things" to monitor and collect real-time data in order to optimise system performance (e.g. through preventive maintenance). 
Journal of Cleaner Production, https://doi.org/10.1016/j.jclepro.2019.02.045

Table 2 Opportunities and challenges for implementing virtualise, share and optimised CE actions by the University of Manchester. CE actions $\begin{array}{lll}\text { CE case } & \text { Value proposition } & \text { Value creation, delivery and capture }\end{array}$

Virtualise $\quad$ Philips and Pay-per-lux: pay $\quad \circ$ Full life cycle management of energy(dematerial Turntoo ${ }^{a}$ only for the light; not efficient lighting, including preventive ise; access the equipment maintenance and system optimisation to productsasservices)

\begin{tabular}{lll}
\hline $\mathrm{HP}^{\mathrm{b}}$ & $\begin{array}{l}\text { All-in-one solutions } \\
\text { offered on a per- } \\
\text { seat/per-month } \\
\text { basis }\end{array}$ \\
\hline Bundles and & $\begin{array}{l}\text { Clean clothes on a } \\
\text { pay-per-wash basis }\end{array}$
\end{tabular}

Full life cycle management of IT devices, including proactive intelligence to optimise device productivity based on fleet location and condition

\section{Opportunities and benefits}

\section{Challenges and requirements}

$\checkmark$ Implementation in university libraries, meeting places and student

Legal agreements and length of residences contracts

$\square$ Cost personalisation

Miele pay-per-wash basis

of high guality washing and refurbishment the use of digital technologies

HP is a supplier of university IT

冈 User behaviour and associated costs equipment

New type of contracts

$\square$ Implementation and management by the university IT service

$\square$ Better laundry service for students

$\checkmark$ Student engagement in sustainability practice through data sharing

Balance a service-offering with the required changes in user behaviour and expectations

\begin{tabular}{llll}
\hline REEPa & $\begin{array}{l}\text { Closed-loop reuse } \\
\text { of printing paper }\end{array}$ & $\circ \begin{array}{l}\text { A multi-functional printer contains a device } \\
\text { (laser) that erases the toner from ablation }\end{array}$
\end{tabular}
resistant pape

- Documents are scanned and saved into the cloud

$\square$ Implementation in administrative buildings

冈 Management of safety and risks

$\checkmark$ Reduction of paper consumption and

Change in customer behaviour simplification of administrative processes

\begin{tabular}{llrl}
\hline Rype Office $^{\mathrm{a}}$ & $\begin{array}{l}\text { Furniture } \\
\text { refurbishment and } \\
\text { remanufacture }\end{array}$ & $\circ$ & $\begin{array}{l}\text { High-quality and easy to remanufacture } \\
\text { furniture }\end{array}$ \\
& $\circ \begin{array}{l}\text { Furniture refurbishment or leasing for a } \\
\text { monthly fee or sold with a buy-back offe }\end{array}$
\end{tabular}

$\checkmark$ High applicability through new tender

If the papers is not used in the same place it could be lost, leading to buying more paper

$\square$ Leasing schemes to replace current

冈 System management monthly fee or sold with a buy-back offer narrow and conservative contracts

$\mathrm{BAMB}^{\mathrm{a}}$

- Electronic material passports to recover Flexible building design for material recovery

- Protocols to develop flexible and

$\square$ Support for daily construction practice and development of new policies and circularity rating systems for buildings

transformable buildings, easy to maintain, repair and refurbish

\section{Share}

(maximise

assets use;

prolong

service life)

\begin{tabular}{|c|c|c|c|}
\hline Lloyds Bank $^{d}$ & $\begin{array}{l}\text { Flexible working } \\
\text { and office space } \\
\text { use }\end{array}$ & O & $\begin{array}{l}\text { Introduction of flexible working protocols to } \\
\text { optimise office space usage and staff } \\
\text { performance }\end{array}$ \\
\hline
\end{tabular}

\begin{tabular}{ll}
\hline Airbnb $^{d}$ & $\begin{array}{l}\text { Renting of spare } \\
\text { rooms in private } \\
\text { residences }\end{array}$
\end{tabular}

- Asset optimisation through renting of under-utilised space in private residences

\begin{tabular}{ll} 
Floow2 $^{\mathrm{a}}$ & $\begin{array}{l}\text { Business-to- } \\
\text { business sharing }\end{array}$ \\
\hline
\end{tabular}

- Platform to enable organisations to advertise and share overcapacity of

\begin{tabular}{|c|c|}
\hline $\begin{array}{l}\square \text { Flexible and adaptable space } \\
\text { considering specific needs for } \\
\text { teaching and research } \\
\square \text { Seasonal offering of space for } \\
\text { sharing }\end{array}$ & $\begin{array}{l}\otimes \text { Measuring the benefits of sharing } \\
\text { activities } \\
\otimes \quad \text { Conservative mind-sets and cultural } \\
\text { barriers }\end{array}$ \\
\hline $\begin{array}{l}\square \text { Application in students residences } \\
\square \text { Seasonal offering of spare rooms } \\
\text { and space through strategic } \\
\text { partnerships }\end{array}$ & $\begin{array}{l}\text { Identifying innovative solutions for } \\
\text { space sharing across the university }\end{array}$ \\
\hline$\square$ Services centralisation & 凶 Risk and safety issues \\
\hline
\end{tabular}

冈eliability and practicality

\ Legislation changes to facilitate circular construction processes

Measuring the benefits of sharing ching and research

Conservative mind-sets and cultural

Identifying innovative solutions for 


\begin{tabular}{|c|c|c|c|c|c|}
\hline $\begin{array}{l}\text { CE } \\
\text { actions }\end{array}$ & $\begin{array}{l}\text { CE case } \\
\text { studies }\end{array}$ & Value proposition & Value creation, delivery and capture & Opportunities and benefits & Challenges and requirements \\
\hline & & $\begin{array}{l}\text { marketplace for } \\
\text { equipment and } \\
\text { people }\end{array}$ & $\begin{array}{l}\text { equipment and skills of personnel that are } \\
\text { under-utilised }\end{array}$ & $\begin{array}{l}\text { Help staff to look for reusable } \\
\text { equipment before purchasing new } \\
\text { units }\end{array}$ & $\begin{array}{l}\text { Allocation of competences between } \\
\text { actors }\end{array}$ \\
\hline & $\begin{array}{l}\text { Universities } \\
\text { of Michigan } \\
\& \text { Boston }^{e}\end{array}$ & $\begin{array}{l}\text { Reusable mugs and } \\
\text { food containers in } \\
\text { the campus } \\
\text { canteens }\end{array}$ & $\begin{array}{l}\begin{array}{l}\text { Mugs and food containers are offered at } \\
\text { low cost }\end{array} \\
\text { Discounts and access to the express Green } \\
\text { Line } \\
\text { Products are cleaned and redistributed or } \\
\text { refunded }\end{array}$ & $\begin{array}{l}\text { Replacement of disposable } \\
\text { takeaway food containers with } \\
\text { reusable containers }\end{array}$ & $\begin{array}{l}\text { Analysis of cost-effectiveness of the } \\
\text { system } \\
\text { Proper management of supply and } \\
\text { demand, including students } \\
\text { expectations }\end{array}$ \\
\hline \multirow{4}{*}{$\begin{array}{l}\text { Optimise } \\
\text { (increase } \\
\text { system } \\
\text { efficiency; } \\
\text { participate } \\
\text { in reverse } \\
\text { logistics) }\end{array}$} & $\begin{array}{l}\text { Dell and } \\
\text { Goodwill }\end{array}$ & $\begin{array}{l}\text { Upgrading, } \\
\text { remanufacture and } \\
\text { recycling of IT } \\
\text { equipment }\end{array}$ & $\begin{array}{ll}\circ & \text { Gathering of unwanted computers } \\
\circ & \text { Energy-efficient and circular products } \\
\circ & \text { Fully compostable packaging }\end{array}$ & $\begin{array}{l}\square \text { DELL is a supplier of IT equipment } \\
\square \text { Compostable packaging can } \\
\text { increase waste management } \\
\text { efficiency }\end{array}$ & $\begin{array}{l}\text { IT packaging generates waste } \\
\text { management problems in the } \\
\text { university } \\
\text { Need for a takeback system for } \\
\text { packaging }\end{array}$ \\
\hline & $\mathrm{DHL}^{\mathrm{d}}$ & $\begin{array}{l}\text { Collection, recovery } \\
\text { and redistribution of } \\
\text { returned materials } \\
\text { and products }\end{array}$ & $\begin{array}{ll} & \text { Efficient material tracking network } \\
\circ & \text { Service integrated within the delivery } \\
\text { schedule, including on-site de-installation } \\
\text { of finished goods }\end{array}$ & च Takeback system & $\begin{array}{l}\text { Complexity in mapping delivery } \\
\text { points and analysing logistic } \\
\text { requirements } \\
\text { Limited options for some wastes } \\
\text { (e.g. labs) }\end{array}$ \\
\hline & Cirkle $^{\mathrm{c}}$ & $\begin{array}{l}\text { Delivery of local } \\
\text { goods with a return } \\
\text { service for } \\
\text { household wastes }\end{array}$ & $\begin{array}{ll}\circ & \text { Collection of over } 20 \text { waste streams } \\
\circ & \text { Reusable products are sent to charities } \\
\circ & \text { Recyclable materials are sent to recyclers }\end{array}$ & $\begin{array}{l}\square \text { A return system for plastic and glass } \\
\text { bottles in student residences and } \\
\text { canteens }\end{array}$ & $\begin{array}{l}\text { 冈 Changing people's minds and } \\
\text { behaviour }\end{array}$ \\
\hline & $\begin{array}{l}\text { Desso and } \\
\text { Interface }\end{array}$ & $\begin{array}{l}\text { Reutilisation and } \\
\text { recycling of modular } \\
\text { carpet tiles }\end{array}$ & $\begin{array}{l}\text { Leasing schemes and take-back } \\
\text { programmes } \\
\text { Modular tiles with recyclable yarn that can } \\
\text { be separated from the backing for reuse }\end{array}$ & $\begin{array}{l}\text { The university is already working } \\
\text { with Desso on some refurbishment } \\
\text { activities with the purpose of reusing } \\
\text { carpets }\end{array}$ & $\begin{array}{l}\text { Analysis of technical and economic } \\
\text { aspects of using waste materials in } \\
\text { construction projects }\end{array}$ \\
\hline
\end{tabular}

'Circle Economy (2017).

dArup (2016).

eUniversity website.

'DELL (2017). 
Accordingly, "virtualise" was perceived by the participants as a relevant CE strategy for a greater control of the management of campus operations (e.g. use of products), design of a more comfortable built environment (e.g. lighting in buildings), development of innovative value-capture mechanisms (e.g. students' personalised fees) and engagement of staff and students in sustainable resource use (e.g. data gathering and analysis). Relevant challenges to overcome include conservative mind-sets and behaviour, governance structures (e.g. procurement contracts), safety and risk management and knowing when it is the right time to act (e.g. cost-effectiveness).

\subsubsection{Share business model innovations}

The case studies presented in Table 2 show how different companies are contributing to a CE by introducing flexible working schemes, renting spare space, operating sharing platforms and offering reusable products. The implementation of such activities within the university would involve changing governance structures, procurement mechanisms and behaviour.

Currently, the university offers researchers the possibility to search for equipment using an online inventory system (N8 2017). As a result, researchers can rent and share the equipment rather than purchasing new items. Accordingly, the design of flexible spaces and seasonal renting of spare space was perceived as a more relevant strategy to optimise space usage across the campus, considering that the space utilisation rate in the whole university is equivalent to $20 \%$ (UoM 2010). The implementation of a centralised university security and administrative management system in collaboration with the neighbouring Manchester Metropolitan University was also considered important for optimising resource use.

In addition to offering reusable mugs to students on campus, participants also thought that the same concept could be applied to disposable food containers to reduce waste generation. Relevant challenges to overcome for the implementation of this and other sharing activities include cultural barriers, students' expectations, allocation of resources between various university units and lack of tools and data to obtain necessary estimates. However, these limitations could be extrapolated to any activity related to "sharing" within and beyond HEIs.

\subsubsection{Optimise business model innovations}

The workshop participants agreed that none of the optimised case studies was a priority for the university. Although the university can benefit from takeback systems, there are internal constraints to tracking material flows and storing waste on campus until it can be collected by contractors. Likewise, contractors do not accept some waste streams, such as lab materials and equipment. The university has also implemented IT and furniture reuse centres to collect, repair and redistribute equipment locally. So, the organisation is already contributing to optimising the usability of some products.

The participants were also interested in finding solutions for optimal management of packaging materials that are particularly problematic for the university, such as polystyrene, as well as mattresses from student residences (Table 2). Implementing return systems (e.g. reverse vending machines) for the collection of plastic and glass bottles was also considered a relevant area for exploration to facilitate effective waste management in student residences. However, the participants stressed the importance of determining the cost-effectiveness of this system.

All these findings led to the prioritisation of a number of key CE actions that can constitute a flexible platform for supporting the organisation's transition towards a CE, as discussed in the next section.

\subsubsection{Prioritisation of CE business model innovations}

Figure 4 presents the priority actions agreed by the workshop participants to start implementing CE business model innovations in the university. Only four out of $14 \mathrm{CE}$ strategies (Table 2) were chosen by the participants; three strategies correspond to virtualise and one to share actions. These CE actions were considered technically and economically feasible (see Figure 2) allowing the organisation to take simple but practical incremental steps for supporting sustainable resource management across the campus. Thus, they represent an opportunity for the university to overcome some of the barriers described in Table 1 and move a step closer to the achievement of the CE 
vision (Section 3.2.1). These actions were also assumed to have the potential to improve the overall resource efficiency and sustainability performance of the university based on the opportunities identified in Section 3.2.2.

\begin{tabular}{|c|c|}
\hline $\begin{array}{c}\text { 1- Circular furniture } \\
\text { (virtualise) }\end{array}$ & $\begin{array}{c}\text { •Encourage refurbishment of existing stock } \\
\text { - Lease remanufactured furniture }\end{array}$ \\
\hline $\begin{array}{c}\text { 2- Circular mugs and } \\
\text { food containers } \\
\text { (share) }\end{array}$ & $\begin{array}{c}\text { - Offer students the purchase of reusable products } \\
\text {-Implement takeback system for cleaning }\end{array}$ \\
\hline $\begin{array}{c}\text { 3- Circular } \\
\text { appliances } \\
\text { (virtualise) }\end{array}$ & $\begin{array}{l}\text {-Pay-per-use fridges and vacuum cleaners for } \\
\text { students in university residences }\end{array}$ \\
\hline $\begin{array}{c}\text { 4- Circular lighting } \\
\text { (virtualise) }\end{array}$ & $\begin{array}{l}\text {-Pay-per-lux to avoid purchasing and maintaining } \\
\text { lighting equipment }\end{array}$ \\
\hline
\end{tabular}

Figure 4 Priority actions to start implementing CE business model innovations by the university.

\subsubsection{Circular furniture}

Refurbishment of the existing stock and access to remanufactured products through leasing was selected as the most relevant priority action. To be able to refurbish the furniture, the university needs to develop a dynamic monitoring system to inventory, track and check the location, condition and availability of the furniture across the campus. It is also important to create a working team and allocate space to undertake refurbishments, if they were to take place on campus. Here, the university could take advantage of the already implemented furniture-for-reuse store. If new furniture is required due to the growing number of students and staff joining the university, the procurement office could integrate CE criteria into new tender processes, requiring from suppliers full life cycle management of remanufactured furniture or new products with a buy-back offer (see Rype Office in Table 2).

\subsubsection{Circular mugs and food containers}

This entails offering students the possibility to purchase reusable products to eat and drink on campus, including the implementation of takeback systems to clean and redistribute the products. According to the information provided by the procurement office, students and staff consume around 100,000 disposable cups and 93,000 disposable food containers annually. Considering an average weight of $12 \mathrm{~g}$ for disposable cups and $18 \mathrm{~g}$ for disposable food containers (Gallego-Schmid et al. 2019), the amount of waste generated per year is equivalent to 2.9 tonnes. Consequently, the promotion of reusable mugs and food containers in substitution of takeaway food packaging could reduce drastically waste generation and the associated environmental impacts. It can also serve as a vehicle to raise awareness and engage students and staff in sustainability practice by offering discounts and special offers, such as express 'green line' access to purchase food.

\subsubsection{Circular appliances}

This activity involves the delivery of products as services through pay-per-use contracts (Figure 4). The university is already offering students a centralised laundry service. Consequently, the implementation of pay-per-wash in individual residences would not be efficient and cost-effective (see Bundles and Miele, Table 2). However, this model can be applied for fridges and vacuum cleaners in student residences. According to the workshop participants, there are many fridges and vacuum cleaners underutilised or not used at all in student residences. As a result, there is a mix of under-utilised old and brand-new products. Accessing these products as a service could increase system efficiency with the corresponding economic and environmental savings. Likewise, data 
Journal of Cleaner Production, https://doi.org/10.1016/j.jclepro.2019.02.045

gathering on product performance over time (e.g. resource consumption) through digital technologies can serve as a vehicle to offer students a better service (e.g. personalised solutions) and raise their sustainability awareness. However, it is important to balance properly a service with safety and risk issues and the required changes in student behaviour and expectations (Table 2).

\subsubsection{Circular lighting}

Circular lighting refers to pay-per-lux contracts to avoid purchasing and maintaining lighting equipment and installations (Figure 4). Workshop participants found Philips CE business model (Table 2) quite novel and creative with the potential to bring significant energy and cost savings for the university. Accessing such service could also enhance space comfort. It can also support the design of mechanisms for personalised charging of students for energy use in residences. However, this charging system would require the deployment of an extensive network of sensors and data analysis software to monitor electricity usage in buildings and allocate electricity consumption per space and person, which may be complex and costly. Other relevant challenges include overcoming legal barriers, conservative procurement processes and implications for the maintenance staff (Table 2).

These four strategic CE actions can drive business model experimentation to explore diverse possibilities and scale up those solutions that can lead to greater positive impacts in the long term.

\section{Discussion}

\section{1. $\quad$ Critical assessment of the research methodology and outcomes}

The background analysis and semi-structured interviews (Section 2.2.1) allowed getting an overview of the scope and effectiveness of the corporate sustainability policies currently in place within the university. The findings were also useful to customise the design and development of the participatory workshops (Section 2.2.2) for the identification of gaps for improvements and the prioritisation of actions for building a business case for implementation of CE in the university.

The use of graphical resources to present and describe the CE concept, its practical applicability and potential sustainability benefits (Section 2.2.2.1) was useful for facilitating the understanding and encouraging creative thinking among the workshop participants. The Circular and Sustainable Business Model Canvas (Figure 3), the ReSOLVE checklist (EMF 2015) and the inspiring CE case studies (Table 2) led to the prioritisation of four strategic actions (Figure 4) for implementation of business model innovations for sustainable resource management.

These CE actions (furniture, mugs and food containers, appliances and lighting) have been considered a key starting point to help overcome organisational and operational barriers (Table 1) and redesign the university's business model (Figure 3 ) by taking incremental steps. There was a consensus that these actions can constitute a flexible platform for the next steps needed to achieve the organisation's overarching CE vision (section 3.2.1). Consequently, this action-led research was instrumental in initiating procedures for the development of a CE programme that will help achieve the targets set in the university's Sustainable Resources Plan (UoM 2017a).

However, the implementation of CE business model innovations requires an ongoing iterative process of continuous organisational learning and operational change (Senge et al. 2006; Benn et al. 2013). It includes experimentation and piloting to overcome inertia, testing the feasibility and suitability of alternative solutions and exploring the implications of gradually transforming a business model from "linear" to "circular" (Weissbrod and Bocken 2017; Rytkönen and Nenonen 2014). In this process, universities must learn how to collaborate with and benefit from partners, suppliers and customers by practising CE and sustainability proactively in the management of campus operations.

By promoting innovative CE approaches and practices in campus management, HEls can learn how service providers, industry and society as a whole can maximise CE and sustainable value (FerrerBalas et al. 2010). This can be achieved through university living labs for sustainability, the social responsibility challenges and other sustainability engagement programmes in place (Section 3.2.2). Likewise, HEls can actively influence external stakeholders by showcasing the benefits of 
implementing CE and sustainability solutions internally in ways that all those who engage with the university will recognise, learn from and emulate (Stephen et al. 2008). These CE practices, including the principles and criteria behind, can be transferred to partners, suppliers and customers via different dissemination channels as well as using different instruments, such as the NETpositive engagement tool used by the procurement office to engage suppliers in sustainability practice (Section 3.2.2.). Likewise, large HEls can actively influence suppliers and manufacturers to deliver resource efficient product-service systems through the integration of CE specifications in tendering processes.

Finally, the use of robust analytical tools and meaningful KPIs is crucial for measuring the potential sustainability benefits and trade-offs of different CE solutions. In this process, the possible rebound effects and environmental burden shifting derived from different CE actions should be carefully assessed. However, such tools and indicators for use in HEls are still lacking and further research should focus on addressing this challenge.

\subsection{Opportunities to integrate CE principles within sustainability management processes}

Given that the CE concept can be considered a subset of the broader sustainability realm (Bocken et al. 2014), it is appropriate to assume that CE principles should be integrated within the sustainability management systems used by HEls (Mendoza et al. 2018). Thus, learnings from sustainability management can be taken into account to facilitate an integrated and systemic CE implementation, as described below.

For sustainability, and by extension for a circular economy, to become an integral part of HEls' systems, it needs to be put into practice long enough until wide-spread implementation and stabilisation (Lozano et al. 2015a). University leaders and staff must be empowered to catalyse and implement CE innovations as an instrumental pathway to ensure organisational sustainable development. In this process, it is important to overcome the resistance to change due to conservative mind-sets and rigid governance structures (Mendoza et al. 2019). This also calls for collaboration with other universities and relevant stakeholders, embedding CE systematically within the institutional frameworks and developing practical on-campus experiences (Lozano et al. 2015a, 2015b). According to Blok et al. (2015), leadership support and exemplary pro-environmental behaviour by leaders helps to catalyse pro-environmental behaviour in the workplace and it generates significantly positive impacts on employees' intentions to act pro-environmentally.

Appropriate target setting, effective KPIs and appropriate CE and sustainability strategies are also essential for driving meaningful changes (Robinson et al. 2015). However, HEls' sustainability management and reporting systems need further development by embedding CE thinking fully (Mendoza et al. 2019). In this process, in-depth understanding of human-related barriers to the integration of CE and sustainability management in HEls is crucial. Verhulst and Lambrechts (2015) argue that differences in human behaviour could support or hamper the successful implementation and management of sustainability management systems. Consequently, it is essential to apply usercentred approaches in the evaluation of the potential implications of CE and sustainability-oriented business model innovations and create suitable data gathering systems and assessment, monitoring and reporting mechanisms.

Lozano et al. (2015b) also highlight a strong relationship between sustainability commitment, implementation and signing of sustainability-oriented declarations, charters and initiatives by HEls. This must be taken into consideration when HEls aim to pursue CE implementation. In this research, the proposed CE framework was used to initiate the procedures for the development of a CE programme and help achieve the targets described in the university's Sustainable Resources Plan (UoM 2017a). As a result, the following was integrated in the Plan (page 5): "Align with the principles of the circular economy - Review the results of the bespoke circular economy research to implement measures that support targets detailed in this Plan". This is an important first step towards making the CE mainstream.

Finally, by managing CE actions through a systematic approach (e.g. from a participatory top-down and bottom-up implementation and monitoring), HEls can serve as living labs and role models for 
sustainability (Omrcen et al. 2018). These living labs have the power to harness the academic and research capacity of universities to address the challenges of CE deployment and sustainable development (König and Evans 2013). They can also help to transfer CE and sustainability innovations across the cities and regions where HEls are placed (Kılkış 2017), considering that experimentation in living labs could go beyond technological development and expand to include planning practices and societal issues (Hua 2013). Living labs are also useful for monitoring the social and physical impacts of CE and sustainability-oriented activities and solving real-world problems (Omrcen et al. 2018). Thus, they can assist in realising a more sustainable society overall (Kılkış 2017). Likewise, the implementation of living labs for CE and sustainability experimentation can help co-design robust data collection and monitoring systems able to support the development of meaningful business cases to drive institutional change and innovation processes.

\subsection{Limitations and further research needs}

The research findings have demonstrated the usefulness of the BECE framework (Mendoza et al. 2017) in raising awareness, engaging stakeholders and supporting a structured analysis of key intervention areas to enhance organisational circularity and sustainability performance.

However, the BECE framework was only applied partially in this study with only the top-down backcasting-related activities performed. Although four CE action lines were identified (Figure 4), an eco-design analysis could not be performed to guide business model innovations from the bottomup due to the constraints encountered in data collection. Several post-workshops meetings were held in an attempt to gather quantitative inventory data on energy, material and waste flows. However, the financial models used by the university procurement office do not capture the required detail. As a result, the eco-design analysis of CE innovations (Figure 4) could not be developed to validate their suitability.

Therefore, future research should analyse the effectiveness of bottom-up CE strategies. This includes the engagement of relevant stakeholders, including the students, to provide feedback on the identified CE solutions and propose others. Further research should also carry out quantitative evaluations of the potential implications and expected benefits of the CE solutions by analysing how they can improve customer needs and experience.

Another potential limitation of the research is the small sample of inspirational case studies to encourage CE thinking among the workshop participants. The case studies might have conditioned participants to think only about those strategies that were presented to them rather than envisioning more radical solutions for application in the university context. Personal interests, motivations, knowledge and expertise could have affected the project outcomes as well. For instance, not all the participants had expert knowledge about the business model of the university, including the application of business model thinking to identify improvement opportunities. Filling in the CSBMC was therefore a complex task. Furthermore, each department within the university has its own value propositions and value creation, delivery and capture mechanisms. Thus, the CSBMC might be more useful to analyse departments or divisions rather than the university as a whole. This might provide more specific and practical results.

Finally, people from different disciplines were present in the workshops. While this made the workshops richer, it was at the same time a limitation because some participants felt they did not have the required technical knowledge about CE implementation to contribute meaningfully to the debates. This could have reduced the number of creative ideas generated and evaluated. Nevertheless, all the participants agreed on the resulting CE strategic action lines, which means they have all perceived their value for the organisation as a whole.

\section{Conclusions and recommendations}

This paper presented the outcomes of action-led research used to identify, evaluate and prioritise intervention areas for implementation of CE business model innovations in a university context. The University of Manchester was used as an illustrative example of a $\mathrm{HEI}$. 
Using the BECE framework, the research involved a background analysis and semi-structured interviews (exploration), participatory workshops (assessment) and a critical evaluation of the outcomes (reflection). A novel combination of supporting analytical tools (e.g. Circular and Sustainable Business Model Canvas, ReSOLVE Checklist and Opportunity Prioritisation Matrix) and supporting material (case studies) were used to facilitate this process. This combination of tools and supporting material, not attempted previously, was demonstrated to be useful for facilitating a structured identification, assessment and prioritisation of CE solutions. It was also useful for obtaining a buy-in from relevant stakeholders with different roles and responsibilities that have the power to drive change within the organisation.

The literature so far has focused on analysing sustainability management practices by HEls to identify opportunities for reducing their overall environmental footprint. However, little attention has been given to evaluating the implementation of CE business model innovations as an instrumental mechanism for an efficient use of resources and enhanced sustainability performance. Thus, this paper represents a first practical study showing how HEls can apply a step-by-step action-led methodology and toolbox to identify, evaluate and prioritise actions for building a strategy and business case for implementation of a CE in practice.

This research can help to inspire HEls to build a business case for CE implementation. It can also be used as a baseline for development of further studies on how the integration of CE principles can help improve the effectiveness of the sustainability management processes by HEls. Beyond higher education, the proposed methodology can be also applied to drive change in other organisations in the service sector that are looking to move towards a CE. Moreover, the experience and outcomes of this research could serve as a baseline for development of a research agenda for implementation of a CE in HEls and other organisations in the service sector.

Further research should consider some of the challenges identified in this paper, including the lack of leadership teams, supplier engagement and effective policies targeting CE as an instrumental pathway to achieving long-term organisational sustainability. Another relevant challenge to facilitate CE implementation in the university includes the lack of access to appropriate decision-support frameworks, data gathering systems and key performance indicators. The latter could lead to the development of innovative CE policies, standards and reporting frameworks for HEls to monitor and communicate CE progress. These systems could also be used to benchmark HEls based on their circularity and sustainability performance.

\section{Acknowledgements}

The authors would like to thank all the stakeholders that have participated in the semi-structured interviews and workshops, and especially Emma Gardner and Helen Cutts, for their active collaboration in the stakeholder engagement process.

\section{References}

Accenture, 2015. Circular Advantage: Innovative Business Models and Technologies to Create Value in a World without Limits to Growth.

Amit, R., Zott, C., 2012. Creating Value Through Business Model Innovation. MIT Sloan Management Review 53(3): 40-49.

Antikainen, M., Valkokari, K., 2016. A framework for sustainable circular business model innovation. Technology Innovation Management Review 6(7): 5-12.

Arup, 2016. The Circular Economy in the Built Environment. London, UK.

Bakker, C.A., Wang, F., Huisman, J., den Hollander, M., 2014. Products that go round: Exploring product life extension through design. Journal of Cleaner Production 69: 10-16.

Baldassarre, B., Calabretta, G., Bocken, N.M.P., Jaskiewicz, T., 2017. Bridging sustainable business model innovation and user-driven innovation: A process for sustainable value proposition design. Journal of Cleaner Production 147: 175-186.

Bart, M., Thomas, I., 2012. Synthesising case study research: ready for the next step?. Environ. Edu. Res. 18(6): 751 - 764. 
Benn, S., Edwards, M., Angus-Leppan, T., 2013. Organizational Learning and the Sustainability Community of Practice: The Role of Boundary Objects. Organization \& Environment 26(2): 184202.

Blomsma, F., Brennan, G., 2017. The Emergence of Circular Economy: A New Framing Around Prolonging Resource Productivity. Journal of Industrial Ecology 21(3): 603-614.

Bocken, N.M.P., Short, S., Rana, P., Evans, S. 2014. A literature and practice review to develop sustainable business model archetypes. Journal of Cleaner Production 65: 42-56.

Bocken, N.M.P., de Pauw, I., Bakker, C., van der Grinten, B. 2016. Product design and business model strategies for a circular economy. J Ind Prod Eng 33(5): 308-320.

Bocken, N.M.P., Olivetti, E.A., Cullen, J.M., Potting, J., Lifset, R., 2017. Taking the Circularity to the Next Level: A Special Issue on the Circular Economy. J Ind Ecol 21(3): 476-482.

Boons, F., Ludeke-Freund, F., 2013. Business models for sustainable innovation: State-of- the-art and steps towards a research agenda. Journal of Cleaner Production 45: 9-19.

Broman, G. I., Robert, K.H., 2017. A framework for strategic sustainable development. Journal of Cleaner Production 140(1): 17-31.

Bryman, A., Bell, E., 2015. Business Research Methods. Oxford: Oxford University Press.

BSI, 2015. Organizational Resilience: Harnessing experience, embracing opportunity. London: The British Standards Institution (BSI).

BSI, 2017. BS 8001:2017. Framework for Implementing the Principles of the Circular Economy in Organizations - Guide. London: The British Standards Institution (BSI).

Carbon Trust, 2012. Further and higher education: training colleges and universities to be energy efficient. London, UK.

Chesbrough, H., 2007. Business model innovation: it's not just about technology anymore. Strategy \& Leadership 35(6): 12-17.

Circle Economy, 2017. Circular economy reports and insights. Circle Economy. https://www.circleeconomy.com/. Accessed: February 2017.

Crul, M.R.M., Diehl, J.C., 2009. Design for sustainability: A step by step approach. United Nations Environmental Programme (UNEP) and Delft University of Technology.

DELL, 2017. Dell and the circular economy. https://www.dell.com/learn/us/en/uscorp1/corpcomm/circular-economy. Accessed: September 2017.

EAUC, 2016. Insight guide: education for a circular economy. Cheltenham, UK.

EEA, 2016. Circular economy in Europe: Developing the knowledge base. European Environment agency (EEA). Luxembourg: Publications Office of the European Union.

EMF, 2015. Growth Within - A circular economy vision for a competitive Europe. Isle of Wight: Ellen MacArthur Foundation (EMF).

EMF, 2017a. Circular economy case studies. Ellen MacArthur Foundation (EMF). https://www.ellenmacarthurfoundation.org/case-studies. Accessed: February 2017.

EMF, 2017b. The Circular Design Guide. Ellen MacArthur Foundation (EMF) and IDEO. https://www.circulardesignguide.com/. Assessed: February 2017.

Ferrer-Balas, D., Adachi, J., Banas, S., Davidson, C.I., Hoshikoshi, A., Mishra, A., Motodoa, Y., Onga, M., Ostwald, M., 2008. An international comparative analysis of sustainability transformation across seven universities. International Journal of Sustainability in Higher Education 9(3): 295-316.

Ferrer-Balas, D., Lozano, R., Huisingh, D., Buckland, H., Ysern, P., Zilahy, G., 2010. Going beyond the rhetoric: system-wide changes in universities for sustainable societies. J Clean Prod 18: 607610.

França, C.L., Broman, G., Robèrt, K.H., Basile, G., Trygg, L., 2017. An approach to business model innovation and design for strategic sustainable development. Journal of Cleaner Production 140(1): 155-166.

Gallego-Schmid, A., Mendoza, J.M.F., Azapagic, A., 2019. Environmental impacts of takeaway food containers. Journal of Cleaner Production 211: 417-427.

Geissdoerfer, M., Savaget, P., Bocken, N.M.P., Hultink, E.J., 2017. The Circular Economy: A New Sustainability Paradigm? J Clean Prod 143: 757-768.

Heyes, G., Sharmina, M., Mendoza, J.M.F., Gallego-Schmid, A., Azapagic, A. 2018. Developing and implementing circular economy business models in service-oriented technology companies. Journal of Cleaner Production 177: 621-632. 
Journal of Cleaner Production, https://doi.org/10.1016/j.jclepro.2019.02.045

Hoover, E., Harder, M., 2015. What lies beneath the surface? The hidden complexities of organizational change for sustainability in higher education. J. Clean. Prod. 106: 175-188.

HP, 2017. HP Devise as a service (DaaS). https://www8.hp.com/h20195/v2/getpdf.aspx/4AA65363ENW.pdf. Accessed September 2017.

Hua, Y. (2013) 'Sustainable campus as a living laboratory for climate change mitigation and adaptation: the role of design thinking processes'. Regenerative Sustainable Development of Universities and Cities. Northampton: Edward Elgar Publishing, Inc.

Johannsdottir, L. 2014. Transforming the linear insurance business model to a closed-loop insurance model: a case study of Nordic non-life insurers. Journal of Cleaner Production 83: 341-355.

Joyce, A., Paquin, R.L., 2016. The triple layered business model canvas: A tool to design more sustainable business models. Journal of Cleaner Production 135(1):1474-1486.

Kathryn, H., Anderson, G.L., 2005. The Action Research Dissertation. US: Sage.

Kılkış, S., 2017. Comparative analyses of sustainable campuses as living laboratories for managing environmental quality. Management of Environmental Quality: An International Journal 28(5): 681-702.

König, A. and Evans, J. (2013) 'Introduction: experimenting for sustainable development? Living laboratories, social learning and the role of the university'. Regenerative Sustainable Development of Universities and Cities. Northampton: Edward Elgar Publishing, Inc.

Kopnina, H., 2018a. Circular economy and Cradle to Cradle in educational practice. Journal of Integrative Environmental Sciences 15(1): 123-138.

Kopnina, H., 2018b. Teaching Circular Economy. Overcoming the Challenge of Green-washing. In: Dhiman, S., Marques, J. (Eds). Handbook of Engaged Sustainability, pp 809-833.

Kraaijenhagen, C., van Oppen, C., Bocken, N.M.P., 2016. Circular Business: Collaborate and Circulate. Circular Collaboration [Amersfoort].

Lewandowski, M., 2016. Designing the business models for circular economy-towards the conceptual framework Sustainability 8: 43.

Lieder, M., Rashid, A., 2016. Towards circular economy implementation: a comprehensive review in the context of manufacturing industry. J Clean Prod 115: 36-51.

Lozano, R., Lukman, R., Lozano, F.J., Huisingh, D., Lambrechts, W., 2015a. A review of commitment and implementation of sustainable development in higher education: results from a worldwide survey. J. Clean. Prod. 48: 10-19.

Lozano, R., Ceulemans, K., Alonso-Almeida, M., Huisingh, D., Lozano, F.J., Waas, T., Lambrechts, W., Lukman, R., Hug, J., 2015b. A review of commitment and implementation of sustainable development in higher education: results from a worldwide survey. J. Clean. Prod. 108: 1-18.

McDonough, W., Braungart, M., 2002. Cradle to cradle: Remaking the way we make things. North Point Press, New York.

McDonough, W., Braungart, M., 2013. The Upcycle: Beyond Sustainability - Designing for Abundance. North Point Press, New York.

Mendoza, J.M.F., Sharmina, M., Gallego-Schmid, A., Heyes, G., Azapagic, A., 2017. Integrating backcasting and eco-design for the circular economy: the BECE framework. Journal of Industrial Ecology 21(3): 526-544.

Mendoza, J.M.F., Gallego-Schmid, A., Azapagic, A., 2019. Exploring the implementation of circular economy thinking in higher education institutions. Journal of Cleaner Production.

Mitchell, D., Coles, C., 2003. The ultimate competitive advantage of continuing business model innovation. Journal of Business Strategy 24(5): 15-21.

Moreno, M., De los Rios, C., Rowe, Z., Charnley, F., 2016. A Conceptual Framework for Circular Design. Sustainability 8(9): 937.

Murray, A., Skene, K., Haynes, K., 2017. The Circular Economy: An Interdisciplinary Exploration of the Concept and Application in a Global Context. J Bus Ethics (140): 369-380.

NETpositive Futures 2017. NETpositive Supplier Engagement Tool (HE). http://netpositivefutures.co.uk/netpositive-supplier-engagement/. Accessed: September 2017.

N8, 2017. the N8 Shared Equipment Inventory System. http://www.n8equipment.org.uk/. Accessed: September 2017.

OECD, 2010. Higher education for sustainable development. Final Report of International Action Research Project. Organisation for Economic Cooperation and Development (OECD).

Omrcen, E., Lundgren, U. Dalbro, M., 2018. Universities as role models for sustainability: a case study on implementation of University of Gothenburg climate strategy, results and experiences 
Journal of Cleaner Production, https://doi.org/10.1016/j.jclepro.2019.02.045

from 2011 to 2015'. International Journal of Innovation and Sustainable Development 12 (1/2): 156-182.

Osterwalder, A., Pigneur, Y., 2010. Business Model Generation - a Handbook for Visionaries, Game Changers, and Challengers. US: Wiley.

Pauli, G., 2010. The Blue Economy: 10 years -100 innovations - 100 million jobs. US: Redwing Book Company.

Pomponi, F., Moncaster, A., 2017. Circular economy for the built environment: A research framework. Journal of Cleaner Production 143: 710-718.

Rammelt, C., Crisp P., 2014. A systems and thermodynamics perspective on technology in the circular economy. Real-world Econ Rev 68: 25-40.

Richardson, J. 2008. The business model: An integrative framework for strategy execution. Strategic Change 17(5-6): 133-144.

Robson, C., McCartan, K.,. 2015. Real World Research. US: Wiley.

Rytkönen, E., Nenonen, S., 2014. The Business Model Canvas in university campus management. Intelligent Buildings International, 6(3): 138-154.

Schaltegger, S., Lüdeke-Freund, F., Hansen, E.G., 2012. Business cases for sustainability: the role of business model innovation for corporate sustainability. International Journal of Innovation and Sustainable Development 6(2) 95-119.

Senge, P., Lauer, J., Schley, S., Smith, B., 2006. Learning for Sustainability. Cambridge, MA: The Society for Organizational Learning, Inc.

Somekh, B. 2006. Action Research: A Methodology for Change and Development. US Open University Press.

Stephens, J.C., Hernandez, M.E., Román, M., Graham, A.C., Scholz, R.W., 2008. Higher education as a change agent for sustainability in different cultures and contexts. Int $\mathrm{J}$ Sustain in Higher Education 9(3): 317-338.

Strategizer, 2015. Why and How Organizations Around the World Apply the Business Model Canvas. https://strategyzer.com/. Accessed: February 2017.

Tiemann, I., Fichter, K., 2015. Developing business models with the Sustainable Business Canvas Manual for conducting workshops. Oldenburg and Berlin.

University of Edinburgh, 2015. Circular economy thinking and action at the University of Edinburgh. https://www.ed.ac.uk/about/sustainability/news/archived-news/2015/circular-economy-reportpublished. Accessed: September 2017.

UoM, 2010. The University of Manchester estates strategy 2010-2020. The University of Manchester (UoM). http://documents.manchester.ac.uk/display.aspx?DoclD=8186. Accessed: September 2017.

UoM, 2012. Campus Masterplan 2012-2022. The University of Manchester (UoM). http://documents.manchester.ac.uk/display.aspx?DoclD=15305. Accessed: September 2017.

UoM, 2015. Manchester 2020: The University of Manchester's Strategic Plan. The University of Manchester (UoM http://documents.manchester.ac.uk/display.aspx?DoclD=25548. Accessed: September 2017.

UoM, 2016. Environmental Sustainability Strategy: building on our heritage to create a sustainable future. The University of http://documents.manchester.ac.uk/display.aspx?DoclD=33155\%20. Accessed: September 2017.

UoM, 2017a. Sustainable Resources Plan: supporting the responsible use of natural resources and materials. The University of http://documents.manchester.ac.uk/display.aspx?DoclD=33195. Accessed: September 2017.

UoM, 2017b. Living Campus Plan. A living campus where we work alongside nature and nature works alongside us. The University of Manchester (UoM). http://documents.manchester.ac.uk/display.aspx?DoclD=33154\%20. Accessed: September 2017.

UoM 2017c. Annual Stocktake Reports. The University of Manchester (UoM). http://www.staffnet.manchester.ac.uk/planning/planningperformancereview/2020stocktake/. Accessed: September 2017.

UoM 2017d. 10,000 Actions. The University of Manchester (UoM). http://www.socialresponsibility.manchester.ac.uk/signature-programmes/10000-actions/.

Accessed: September 2017. 
UoM 2017e. Social Responsibility Signature Programmes. The University of Manchester (UoM). http://www.socialresponsibility.manchester.ac.uk/signature-programmes/. Accessed: September 2017.

UoM 2017f. Measuring the difference - Social and economic impact report 2016/2017. The University of

Manchester

(UoM). http://documents.manchester.ac.uk/display.aspx?DoclD=32801. Accessed: September 2017.

UoM 2018. Facts and Figures 2018. The University of Manchester (UoM). http://documents.manchester.ac.uk/display.aspx?DoclD=35329. Accessed: November 2018.

Upward, A., Jones, P., 2016. An Ontology for Strongly Sustainable Business Models - Defining an Enterprise Framework Compatible With Natural and Social Science. Organization \& Environment 29(1) 97-123.

Vergragt, P.J., Quist, J., 2011. Backcasting for sustainability: Introduction to the special issue. Technological Forecasting \& Social Change 78: 747-755.

WBCSD, 2006. Eco-efficiency Learning Module. World Business Council for Sustainable Development (WBCSD): Switzerland.

Weissbrod, I., Bocken, N.M.P., 2018. Developing sustainable business experimentation capability A case study. Journal of Cleaner Production 142(4): 2663-2676.

Winans, K., Kendall, A., Deng, H., 2017. The history and current applications of the circular economy concept. Renewable and Sustainable Energy Reviews 68(P1) 825-833.

Witjes, S., Lozano, R., 2016. Towards a more Circular Economy: Proposing a framework linking sustainable public procurement and sustainable business models. Resources, Conservation and Recycling 112: 37-44.

Yin, R.K., 2003. Applications of case study research. Thousand Oaks, CA: Sage. 
Journal of Cleaner Production, https://doi.org/10.1016/j.jclepro.2019.02.045

\section{Building a business case for implementation of circular economy in higher education institutions}

Joan Manuel F. Mendoza, Alejandro Gallego-Schmid, and Adisa Azapagic

\section{SUPPORTING INFORMATION}

Table S1 Organisational roles of the interviewed sustainability-related stakeholders.

\begin{tabular}{ll}
\hline Technical & Academic \\
\hline Capital Projects Officer & Lecturer in Sustainable Chemical Engineering \\
Design Services Officer & Professor of Energy Efficiency \\
Environmental Officer of Residential Services & Professor of Environmental Governance \\
Environmental Sustainability Coordinator & Senior Lecturer in Climate Change \\
Environmental Sustainability Officer & \\
Procurement Officer & \\
Technical Services Officer & \\
Waste Management Officer & \\
\hline
\end{tabular}

\section{S1. Semi-structured questionnaire}

\section{Corporate strategy assessment}

Q.1 How was the University's Strategy Plan developed? How were the vision, including the guiding principles and values, the core goals, key strategies and key performance indicators set?

Q.2 Are you familiar with the circular economy concept? Is the concept of circular economy embedded in University's Strategy Plan? How well do you think the Strategy Plan integrates sustainability criteria linked to circular economy principles?

\section{Organisational management}

Q.3 What are the main principles, criteria and aspects guiding the operations of your School/Division? And how do they relate to circular economy and sustainability?

Q.4 How were the environmental sustainability vision, goals and actions included in the Environmental Sustainability Strategy developed? Does your School/Division have its own environmental sustainability plan?

Q.5 What approaches, methods, tools and indicators are used at senior management levels to identify, evaluate and prioritise decisions to address short-, medium- and long-term sustainability challenges, including pursuing a circular economy?

Q.6 Who has developed such sustainability methods, tools and indicators (referred to in the above question)? How has this been done (criteria behind it)? Are they efficient and effective enough for reliable goal setting and achievement?

Q.7 How are decisions taken at the senior management level transferred top-down (communication channels) to different Faculties, Schools and Departments at the University and how do they influence (guide through implementation) downstream operational activities?

Q.8 What kind of criteria, methods, tools and indicators are usually used at the operational levels to identify, evaluate and prioritise sustainable and circular economy decisions? What is the flexibility (freedom) of each Faculty, School, Department and Units to undertake (implement) sustainable actions? 
Journal of Cleaner Production, https://doi.org/10.1016/j.jclepro.2019.02.045

Q.9 How are the operational-level decisions taken in different areas of the University translated bottom-up and how do they influence senior management considerations and decision-making processes related to sustainability?

\section{Improvement opportunities}

Q.10 How can University's decision-making processes be improved at the senior and operational levels to manage comprehensively and more effectively long-term sustainability and circular economy challenges?

\section{S2. Workshop programmes}

\section{S2.1. Workshop A}

Main aim: to explore the circularity and sustainability of the business model of the University of Manchester in order to identify high-level opportunities to develop circular economy strategies.

Objectives:

- To analyse how the university creates, delivers and captures value

- To identify the gaps in the definition, implementation and monitoring of circular economy and sustainability practices and discuss how these gaps could be overcome

- To propose alternatives to develop the business case for circular economy implementation.

Agenda:

\begin{tabular}{|l|l|}
\hline $13: 00-13: 05 \mathrm{~h}$ & Registration, badges and refreshments. \\
\hline $13: 05-13: 15 \mathrm{~h}$ & Welcome and introduction to the workshop \\
\hline $13: 15-13: 25 \mathrm{~h}$ & $\begin{array}{l}\text { Description of the circular economy concept, key principles and case } \\
\text { studies }\end{array}$ \\
\hline $13: 25-13: 45 \mathrm{~h}$ & $\begin{array}{l}\text { Co-creation of a sustainable circular economy vision for the } \\
\text { university }\end{array}$ \\
\hline $13: 45-14: 05 \mathrm{~h}$ & $\begin{array}{l}\text { Analysis of the drivers and barriers for the adoption of the future } \\
\text { vision }\end{array}$ \\
\hline $14: 05-15: 00 \mathrm{~h}$ & Characterisation of the current business model of the University \\
\hline $15: 00-15: 15 \mathrm{~h}$ & Coffee break \\
\hline $15: 15-16: 15 \mathrm{~h}$ & $\begin{array}{l}\text { Mapping high-level opportunities to build the circular economy } \\
\text { business case }\end{array}$ \\
\hline $16: 15-17: 00 \mathrm{~h}$ & Wrap-up: plenary discussions and participants feedback \\
\hline
\end{tabular}

\section{S2.2. Workshop B}

Main aim: to prioritise opportunities and action lines to implement circular economy business model innovations by the university.

Objectives:

- To identify and evaluate intervention areas to develop circular economy studies

- To develop an action plan for the implementation of circular economy solutions. 
Agenda:

\begin{tabular}{|l|l|}
\hline 13:00-13:05h & Registration, badges and refreshments \\
\hline $13: 05-13: 10 \mathrm{~h}$ & Welcome and introduction to the workshop \\
\hline $13: 10-13: 30 \mathrm{~h}$ & $\begin{array}{l}\text { Summary of the outcomes from workshop } \mathrm{A} \text {, interviews and } \\
\text { background analysis }\end{array}$ \\
\hline $13: 30-13: 50 \mathrm{~h}$ & $\begin{array}{l}\text { Presentation of circular economy case studies with application in the } \\
\text { university }\end{array}$ \\
\hline $13: 50-14: 50 \mathrm{~h}$ & $\begin{array}{l}\text { Building the business case for circular economy implementation } \\
\text { (virtualising) }\end{array}$ \\
\hline 14:50-15:00h & Coffee break \\
\hline $15: 00-15: 50 \mathrm{~h}$ & $\begin{array}{l}\text { Building the business case for circular economy implementation } \\
\text { (sharing) }\end{array}$ \\
\hline $15: 50 \mathrm{~h}-16: 25 \mathrm{~h}$ & $\begin{array}{l}\text { Building the business case for circular economy implementation } \\
\text { (optimising) }\end{array}$ \\
\hline $16: 25-16: 45 \mathrm{~h}$ & $\begin{array}{l}\text { Action plan to start implementing circular economy business model } \\
\text { innovations }\end{array}$ \\
\hline $16.45-17: 00 \mathrm{~h}$ & Wrap-up: plenary discussions and participants feedback \\
\hline
\end{tabular}

\section{S3. Handouts shared with the participants}

\section{S3.1. Customer segment}

This refers to different groups of people or organisations with common needs, common behaviours or other attributes an organisation aims to reach and serve. Examples of customer segments are: mass market, niche market, segmented market, diversified market, and multi-sided market. Guiding questions:

\section{Profit-oriented}

- For whom are we creating value?

- Which customer segments are to be served?

- Who are our most important customers?

CE- and sustainability-oriented

- What are the most relevant customers interested in CE and sustainability?

- What significance does sustainability and circular economy have for your customers?

- How customers are engaged in sustainability decision-making?

- How the current value proposition addresses the needs of the customers in a sustainable way?

\section{S3.2. Value proposition}

This describes the bundle of products and services an organisation provides to its customers. The value proposition is aimed at solving a customer problem or satisfies a customer need. Guiding questions:

\section{Profit-oriented}

- What value do we deliver to the customer?

- Which customer needs are we satisfying? Which customer problems are we helping to solve?

- What bundles of products and services are we offering to each customer segment?

- What is unique about your value propositions and why does your customer prefer them to their alternatives? 
Journal of Cleaner Production, https://doi.org/10.1016/j.jclepro.2019.02.045

\section{CE- and sustainability-oriented}

- How are the value propositions aligned with CE principles and sustainability criteria?

- How do the value propositions support the deployment of a sustainable and CE?

- How does the organisation create positive environmental value through its service offering?

- How does the organisation create benefits for the society?

\section{S3.3. Channels}

This describes how a company communicates with and reaches its customer segments to deliver a value proposition. The channels serve several functions, including: raising awareness among customers about a company's products and services, helping customers evaluate a company's value proposition, allowing customers to purchase specific products and services, delivering a value proposition to customers, and providing post-purchase customer support. Guiding questions:

\section{Profit-oriented}

- Through which channels do our customer segments want to be reached?

- How are we reaching them now? How we get the customers attention?

- How are our channels integrated?

- Which ones work best? Which communication and distribution channels are more suitable?

- Which ones are most cost-efficient? How are we integrating them with customer routines?

\section{CE- and sustainability-oriented}

- What are the most resource intensive and environmentally unsustainable channels?

- How do service delivery logistics affect the organisation's sustainability and circularity performance?

- What is the role channels play in getting sustainability and circular economy feedback from customers?

- How do channels contribute to deliver the organisation's sustainability agenda?

- How channels contribute to track resource flows and environmental and social impacts over time?

\section{S3.4. Customer relationships}

This refers to the type of relationships a company establishes with specific customer segments in order to create financial success and sustainability. Customer relationships can be categorised from personal to automate: personal assistance (direct interaction), dedicated personal assistance (very closed interaction), self-service (customer experience), automated service (customised selfservice relationships), communities (share client experiences between customers), co-creation (customer has a direct hand in the form the company's product or service will take). Guiding questions:

\section{Profit-oriented}

- What are the main features of the customer relationship?

- What type of relationship does each of our customer segments expect us to establish and maintain?

- Which ones have we established? How costly are they?

- How are they integrated with the rest of our business model?

- How does the customer interact with you through the sales and product/service life cycles?

\section{CE- and sustainability-oriented}

- How does the organisation manage sustainability impacts?

- How does the organisation influence customers (and other stakeholders) to improve resource efficiency and environmental and social sustainability?

- What is the nature of the relationships with the organisation's stakeholders that is cultivated and maintained for sustainability?

- What relationships would be suitable to build and operate a circular business model?

\section{S3.5. Revenue streams}


This refers to the income a company generates from each customer segment. There are several ways to generate revenue streams, including: asset sale, usage fees, subscription fees, lending/renting/leasing, licensing, brokerage fees, and advertising. Guiding questions:

\section{Profit-oriented}

- Are you charging on value? For what value are our customers really willing to pay?

- For what do they currently pay?

- How are they currently paying?

- How much does each revenue stream contribute to overall revenues?

- Where are you driving revenue and how revenues align with the value propositions?

\section{CE- and sustainability-oriented}

- Does the orientation of the business model toward sustainability enable better access to revenue sources?

- How does the organisation define success environmentally, socially and economically?

- How does the organisation create positive environmental and social value?

- How does the organisation measure the sustainability value of assets?

- How does the organisation calculate revenues (environmentally, socially, financially) generated at any point in time?

\section{S3.6. Key resources}

This refers to the most important/fundamental assets required by the organisation to create and provide value to customers and make a business model work (support business operation), including reaching markets, maintain relationships with customer segments and earn revenues. Key resources can be categorised as physical, financial, intellectual or human. Guiding questions:

\section{Profit-oriented}

- What key resources (tangible and intangible) are required to create value propositions?

- What key resources do our distribution channels require?

- What key resources do our customer relationships require?

- What key resources do our revenue streams require?

- Which ones are already available, which ones must be obtained, or for which ones must partners be found?

\section{CE- and sustainability-oriented}

- What are the key materials (bio-physical stocks) moved, used and/or transformed to render and deliver value propositions?

- How does the organisation deal with the need to reduce resource consumption and environmental impacts?

- Is life cycle thinking applied to identify environmentally, socially and economically suitable resources and guide its sustainable use and end-of-life management?

- Does the university have resources and skills for complying with sustainability and CE requirements, or does it require external support for this?

- How do employees contribute to organisational sustainability management?

- What key resources are important but not aligned with the value proposition and business strategy?

\section{S3.7. Key activities}

These involve the most important actions an organisation must take to operate successfully. Like key resources, they are required to create and offer a value proposition, reach markets, maintain customer relationships, and earn revenues. Like key resources, key activities differ depending on business model type. Examples of some categories of key activities are production, problem solving, and network related activities. Guiding questions:

\section{Profit-oriented}

- What key activities does our business require to create value propositions?

- And our distribution channels?

- And our customer relationships?

- And our revenue streams? 
Journal of Cleaner Production, https://doi.org/10.1016/j.jclepro.2019.02.045

- Which of the activities will we carry out ourselves? For which ones we need partners?

CE- and sustainability-oriented

- What role does sustainability play in the key activities?

- What key activities contribute the most to the organisation's resource consumption and environmental impacts?

- What are the key actions implemented by the organisation to improve resource efficiency and environmental performance?

- What are the key (in-house and outsourced) activities that are necessary to create and deliver functional value but not considered "core" to the organisation?

- How the organisation engage stakeholders in creating sustainability value?

- What key activities are important but not aligned with the value proposition and business strategy?

\section{S3.8. Key partners}

Key partnerships are the network of suppliers and other relevant actors who complement each other to support the organisation create its value proposition and operate a business model. Partnerships can be categorized as strategic alliance between non-competitors, strategic alliance between competitors (coopetition), joint ventures to develop new business and buyer-supplier relationships to assure reliable supplies. Guiding questions:

\section{Profit-oriented}

- Who are our key partners?

- Who are our key suppliers?

- Which key resources are we acquiring from partners?

- Which key activities do partners perform?

- How we do identify, contact and work with key partners?

- Which key resources do you source from partners?

\section{CE- and sustainability-oriented}

- How key partners are engage in resource efficiency and sustainability management?

- What kind of agreements are in place to enhance resource efficiency and sustainability?

- Does the university business model generate additional value for other stakeholders?

- Do certain stakeholders have to be integrated in the development of a sustainable and circular business model?

- What mutually beneficial relationships are built with suppliers, partners and their local communities?

\section{S3.9. Cost structure}

This building block describes the most important costs incurred while operating under a particular business model. It includes costs for creating and delivering value, maintaining customer relationships, and generating revenue. Such costs can be calculated after defining key resources, key activities, and key partnerships. Guiding questions:

\section{Profit-oriented}

- What are the most important costs inherent in our business model?

- Which key resources are most expensive?

- Which key activities are most expensive?

- How key resources and activities drive costs?

\section{CE- and sustainability-oriented}

- What are the most relevant environmental costs related to the university operations?

- Are costs well aligned with the value propositions?

- What are the costs related to the development of resource efficient and environmental actions?

- How costs are reduced by improving resource efficiency and environmental performance?

- What are the most relevant bio-physical measures/metrics used by the organisation to calculate environmental costs? 
- What are the most relevant social costs of the organisation?

- What kind of social indicators are considered and how social impacts are measured?

\section{S3. Analysis of CE drivers and barriers for the University of Manchester}

People and workforce (academics, researchers, and technical staff) were identified as relevant internal drivers to CE implementation in the university because they have the knowledge, expertise and skills required to realise organisational and operational changes. University staff and students can contribute to CE through their participation in the University Living Lab for Sustainability, the Sustainability Enthusiast Network, the 10,000 Actions Signature Programme, the Green Impact Environmental Accreditation Scheme and the Sustainability Grand Challenges (Mendoza et al. 2018). Students can also demand changes towards CE and sustainability through the Student Union. Nevertheless, people were also considered a barrier to CE implementation due to their potential unawareness (ignorance) and lack of involvement in CE practice.

The development of CE-related legislation and the implementation of CE strategies by the Manchester City Council and Greater Manchester region represent important external drivers to boost the development of CE solutions within the university. Other external drivers include the extensive stakeholder network of the university, including partners and suppliers. The delivery of innovative product-service systems by suppliers is crucial for the implementation of a robust CE agenda because the university does not have the required capability to develop certain activities by itself to dematerialise the business model.

The university can influence suppliers through the integration of CE-related specifications in tender processes. The university's NETpositive approach and supplier engagement tool (Netpositive Futures 2017) to reduce negative impacts and enhance positive benefits of procurement activities can contribute also help engaging suppliers in the development of CE activities for application within the university context. The social responsibility corporate goal of the university (UoM 2015), including environmental sustainability, also represents an important driver for CE implementation and the delivery of the Sustainable Resources Plan (UoM 2017a). The furniture for reuse programme is considered one of the most relevant social responsibility initiatives that can enable the mainstreaming of a CE in the whole university (Mendoza et al. 2018). Finally, the university has a large building stock, which is expanding through the development of the ten-year capital investment (£1 billion) Campus Masterplan (UoM 2012). This represents an important driver for CE implementation through the strategic design and life cycle management of innovative buildings and infrastructures.

However, budget limitations (money) and time constraints represent important barriers to develop detailed studies to support CE-informed choices. Likewise, there is a lack of practical guidance, frameworks and tools for universities to ensure improved organisational and operational circularity performance. Accessing to these frameworks would contribute to overcome relevant barriers for CE implementation, such as improving the understanding of the relationship between material consumption and impacts, finding the right waste management solutions, set appropriate building design regulations for strategic construction and refurbishment works, ensure an efficient use of the space, optimise operations and identify key areas to provide incentives and reduce risks.

Another important barrier to overcome relates to students' expectations. According to the workshop participants, each year students aim to receive more value for what they pay (e.g. academic and accommodation fees). However, students' expectations are not always resource efficient and sustainable (e.g. accessing to brand new devices in residences rather than reused products). Consequently, they can limit the implementation of a CE across the campus.

Other important barriers are associated with the conservative culture and rigid governance structure of the organisation that leads to the application of narrow decision-making approaches, which prioritise marginal solutions over more radical innovations, such as product ownership over access to services. Resolving business competing demands and priorities represent also a relevant barrier because the development of high-quality teaching and research activities (corporate strategic goals) usually prevail over sustainability issues (Mendoza et al. 2018). 
It is also worth noting that university operations change over the year. For instance, resource consumption in summer is usually lower than the resource consumption during the rest of the year due to a smaller affluence of students and staff. This seasonal change in campus operations can constraint the development of certain CE strategies that require access to a constant flow of resources, such as the anaerobic digestion on campus to manage organic waste.

Finally, applying to calls from the Higher Education Funding Council for England (HEFCE) can lead universities to develop some activities that may not be inherently resource efficient and sustainable. For instance, universities are encouraged to perform world-class teaching and research to access to funding. However, when researchers need to purchase new research equipment, they usually prioritise the purchase of a high quality unit that will support the successful development of their research activities. This high-quality equipment may lead to higher resource consumption and environmental impacts. Consequently, rising awareness about CE is crucial to facilitate sustainable teaching and research practice (Mendoza et al. 2018). 
Journal of Cleaner Production, https://doi.org/10.1016/j.jclepro.2019.02.045

Table S2. CE case studies (EMF 2017; Circle Economy 2017 and Arup 2016) and opportunities and challenges to implement CE actions in the university

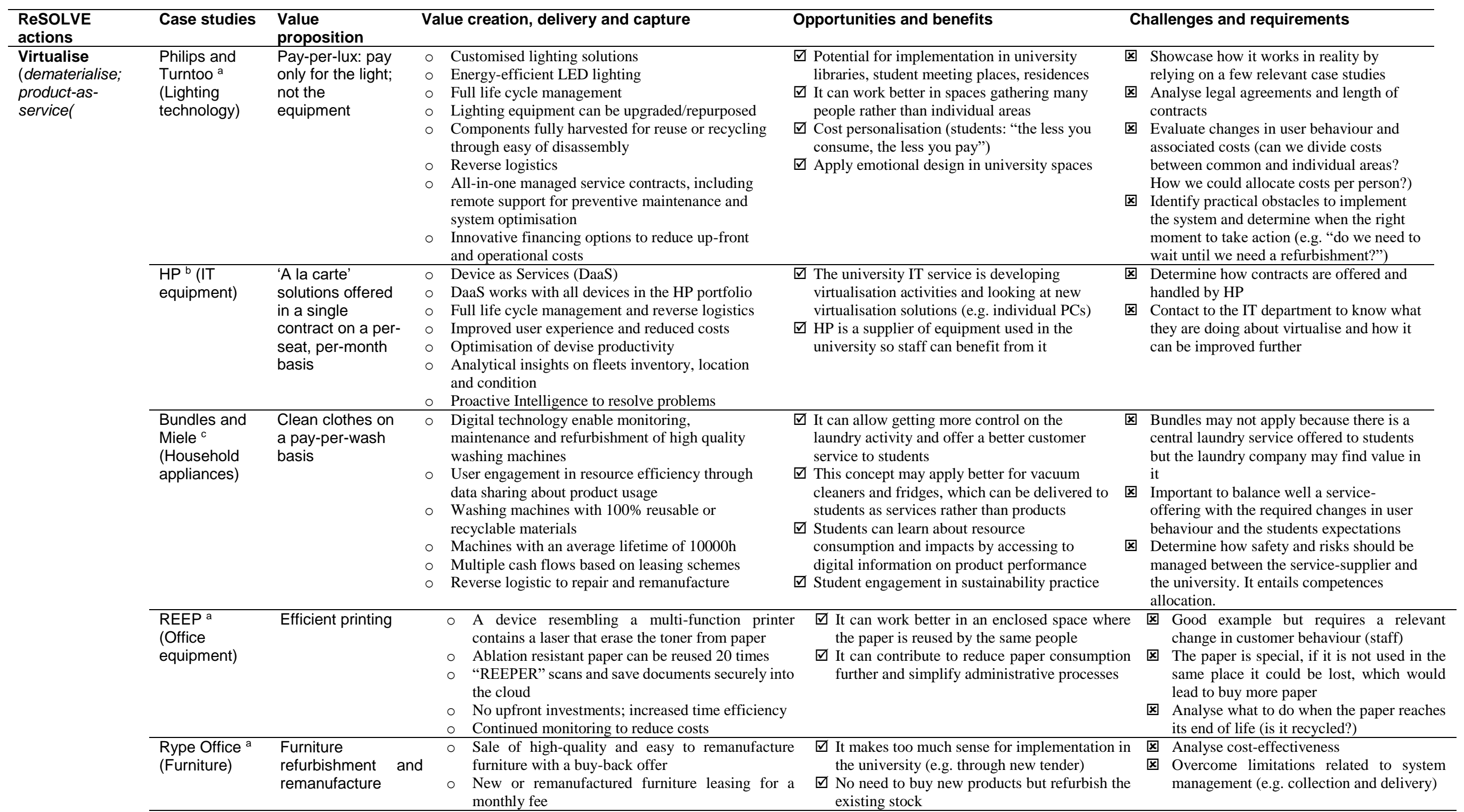


Journal of Cleaner Production, https://doi.org/10.1016/j.jclepro.2019.02.045

- Furniture refurbishment and return to an as-new condition

- Made-to-order service

- Remanufacturing is locally outsourced $\square$ Leasing schemes are interesting because current contracts are narrow and conservative

$\square$ Important to embed this element in new building projects from the outset

$\square$ Great potential to apply this activity in university-related hospitals

$\square$ Building Information Modelling is interesting to know how a building will look like in order to identify points for improvement

(Construction) $\begin{aligned} & \text { Flexible } \\ & \text { reversible building }\end{aligned}$ design to sustain the value of construction materials
Electronic material passports describing characteristics of materials that give them value for reuse and recovery through reverse logistics

- Reversible building design protocol to develop flexible and transformable buildings, easy to maintain, repair and refurbish over time

- Data management system, including building information modelling, for builders to choose healthy, sustainable and circular material $\square$ Guidelines on circular and sustainable

constines on circular and sustainable guidelines (e.g. WRAP) that are difficult to interpret and implement in daily practice

$\square$ It could be lead to develop new policies an rating systems to determine the sustainability and circularity performance of buildings
Take into consideration if it is better to refurbish the existing stock or purchase new furniture with a buy-back offer

冈 Having a catalogue of sustainable furniture products could be a good idea to inform customer choices but it is difficult and timeconsuming (e.g. market changes quickly)

A Analyse relevant case studies to see how it really works and how reliable and practica BAMB offers are.

It is also important to analyse potential legislation changes to facilitate circt construction processes (e.g. how construction waste should be redefined and understood). 
Journal of Cleaner Production, https://doi.org/10.1016/j.jclepro.2019.02.045

\begin{tabular}{|c|c|c|c|c|c|}
\hline $\begin{array}{l}\text { ReSOLVE } \\
\text { actions }\end{array}$ & Case studies & $\begin{array}{l}\text { Value } \\
\text { proposition }\end{array}$ & Value creation, delivery and capture & Opportunities and benefits & Challenges and requirements \\
\hline \multirow[t]{4}{*}{$\begin{array}{l}\text { Share } \\
\text { (maximise } \\
\text { assets use; } \\
\text { durable goods) }\end{array}$} & $\begin{array}{l}\text { Lloyds Bank }{ }^{d} \\
\text { (Office space) }\end{array}$ & $\begin{array}{l}\text { Flexible working } \\
\text { and space use }\end{array}$ & $\begin{array}{l}\text { By introducing flexible working for } 20 \% \text { of its } \\
\text { office space and } 18,000 \text { staff, the Lloyds Banking } \\
\text { Group removed 1,000 desks (London offices) and } \\
\text { saved } £ 10 \mathrm{~m}\end{array}$ & $\begin{array}{l}\text { Flexible working can produce massive savings } \\
\text { in energy and costs } \\
\square \text { It has a high application in the university } \\
\text { where the space utilisation ratio is low } \\
\square \text { It is key to have flexible and adaptable space } \\
\text { considering specific needs for teaching and } \\
\text { research } \\
\square \text { Interesting to have a seasonal offer of } \\
\text { residential and non-residential space for } \\
\text { sharing in different periods of the year through } \\
\text { strategic partnership }\end{array}$ & $\begin{array}{l}\text { 冈 } \begin{array}{l}\text { Determine savings from people working } \\
\text { from home, in shifts or a combination of } \\
\text { both }\end{array} \\
\text { Analyse what kind of data should be } \\
\text { collected and how it should be used to } \\
\text { measure the benefits of sharing } \\
\text { Some faculty members want to have their } \\
\text { own individual space } \\
\text { - } \begin{array}{l}\text { Sharing activities entail a change in staff } \\
\text { mind-sets and behaviour }\end{array} \\
\text { Overcome cultural barriers (e.g. } \\
\text { ownership) }\end{array}$ \\
\hline & $\begin{array}{l}\text { Airbnb }{ }^{d} \\
\text { (Residential } \\
\text { space) }\end{array}$ & $\begin{array}{l}\text { Renting of spare } \\
\text { rooms in private } \\
\text { residences }\end{array}$ & $\begin{array}{ll} & \text { One of the best known examples of the asset } \\
\text { optimisation business model } \\
\circ \\
\circ \text { Guests use } 63 \% \text { less energy than hotel guests } \\
\text { Airbnb guests can save water equivalent to } 1,110 \\
\text { Olympic swimming pools, and } \mathrm{CO}_{2} \text { emissions } \\
\text { equivalent to } 220,000 \text { cars }\end{array}$ & $\begin{array}{l}\square \text { It might be applied in residences during } \\
\text { summer when there are fewer students } \\
\square \text { Spare rooms and space could be offered to the } \\
\text { general public or specific customers }\end{array}$ & $\begin{array}{l}\text { Look for innovative solutions for space use } \\
\text { in the university }\end{array}$ \\
\hline & $\begin{array}{l}\text { Floow2 a } \\
\text { (equipment } \\
\text { and people) }\end{array}$ & $\begin{array}{l}\text { Business-to- } \\
\text { business sharing } \\
\text { marketplace }\end{array}$ & 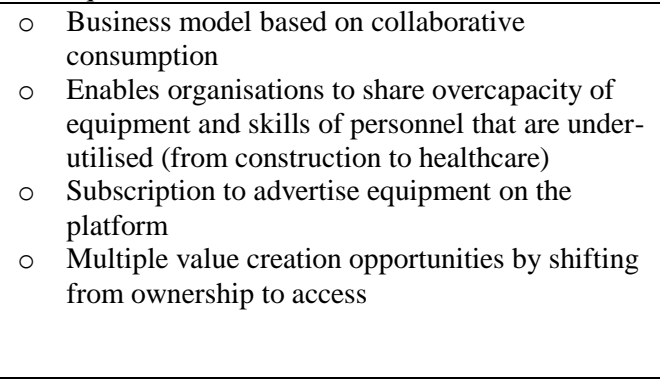 & $\begin{array}{l}\square \text { The university is already sharing equipment } \\
\text { with other universities } \\
\square \text { There is a trend to identify if staff can use high } \\
\text { tech equipment from other places before } \\
\text { purchasing them } \\
\square \text { Equipment is easier to be shared than space } \\
\square \text { Services centralisation (e.g. security and } \\
\text { administration) through partnership with other } \\
\text { universities could be valuable }\end{array}$ & $\begin{array}{l}\text { Safety should be carefully considered } \\
\text { when equipment or space is shared } \\
\text { Sharing works better internally because it } \\
\text { is easier to be managed (e.g. risks). } \\
\text { Sharing people between businesses could } \\
\text { be complex due to legal constraints, } \\
\text { salaries, vacation arrangements, } \\
\text { aspirations, risks. } \\
\text { Find an area to explore the savings that } \\
\text { could be achieved by sharing space vs } \\
\text { equipment }\end{array}$ \\
\hline & $\begin{array}{l}\text { Universities of } \\
\text { Michigan, } \\
\text { Buffalo and } \\
\text { Boston }{ }^{\text {e }} \\
\text { (Catering) }\end{array}$ & $\begin{array}{l}\text { Reusable mugs } \\
\text { and food } \\
\text { containers at the } \\
\text { campus canteens }\end{array}$ & $\begin{array}{ll} & \begin{array}{l}\text { Encouragement of the use of reusable mugs and food } \\
\text { containers in food service areas on campus }\end{array} \\
\circ & \text { Products offered at low cost } \\
\circ & \begin{array}{l}\text { Discounts (e.g. 10\%) in drinks and food purchase by } \\
\text { using reusable mugs and food containers }\end{array} \\
\circ & \begin{array}{l}\text { Drastically reduction in paper, styrofoam and } \\
\text { polystyrene cups and food containers }\end{array} \\
\circ & \text { Discounts in drink and food purchase } \\
\circ & \text { Access to the express Green Line to purchase food } \\
\circ & \begin{array}{l}\text { Reusable mugs and food containers are can be } \\
\text { returned for a clean one or get a refund }\end{array}\end{array}$ & $\begin{array}{l}\text { The University is already giving students } \\
\text { reusable mugs for free. } \\
\square \text { The implementation of reusable food containers } \\
\text { in substitution of takeaway containers is a very } \\
\text { interesting option for exploration. } \\
\square \text { Green line access to food purchase by students } \\
\text { using reusable mugs and food containers is a } \\
\text { great idea easy to implement }\end{array}$ & $\begin{array}{l}\text { Determine how many reusable products } \\
\text { would need to be purchased by the university } \\
\text { to offer this service (including cleaning) to } \\
\text { students } \\
\text { Analyse the cost-effectiveness of the system } \\
\text { Aanage properly supply and demand, } \\
\text { including students expectations } \\
\text { Contact suppliers to develop a good design } \\
\text { and set an appropriate price based on the } \\
\text { volume the university could purchase. }\end{array}$ \\
\hline
\end{tabular}




\begin{tabular}{|c|c|c|c|c|c|}
\hline $\begin{array}{l}\text { ReSOLVE } \\
\text { actions }\end{array}$ & Case studies & $\begin{array}{l}\text { Value } \\
\text { proposition }\end{array}$ & Value creation, delivery and capture & Opportunities and benefits & Challenges and requirements \\
\hline \multirow[t]{4}{*}{$\begin{array}{l}\text { Optimise } \\
\text { (increase } \\
\text { efficiency; } \\
\text { reverse logistics) }\end{array}$} & $\begin{array}{l}\text { Dell and } \\
\text { Goodwill } \\
\text { (IT } \\
\text { equipment) }\end{array}$ & $\begin{array}{l}\text { Upgrading, } \\
\text { refurbishment, } \\
\text { remanufacture } \\
\text { and recycling of } \\
\text { unwanted } \\
\text { computer } \\
\text { electronics }\end{array}$ & 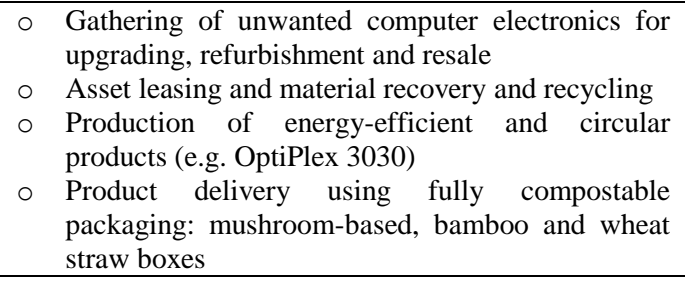 & $\begin{array}{l}\square \text { DELL is a supplier of equipment used in the } \\
\text { university so staff can benefit from it } \\
\square \text { Packaging strategies would produce a kind of } \\
\text { "green waste" easier to be managed }\end{array}$ & 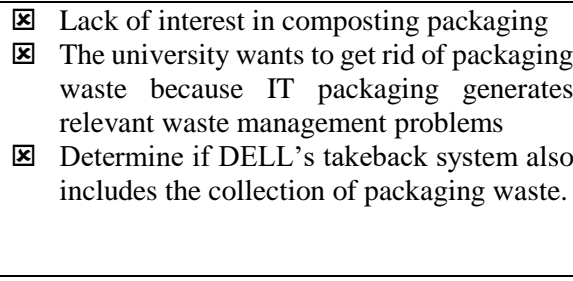 \\
\hline & $\begin{array}{l}\text { DHL d } \\
\text { (Parcel } \\
\text { delivery } \\
\text { logistics) }\end{array}$ & $\begin{array}{l}\text { Collection, } \\
\text { recovery and } \\
\text { redistribution of } \\
\text { returned } \\
\text { materials }\end{array}$ & $\begin{array}{l}\text { DHL is using its vast logistics fleet to track, collect, } \\
\text { recover and redistribute used materials } \\
\text { Service integrated within the delivery schedule, } \\
\text { including on-site de-installation of finished goods } \\
\text { and management of returned materials streams } \\
\text { Partnership with recycling operator to streamline } \\
\text { the return of materials to the economy } \\
\text { Efficient data tracking network to plan ahead based } \\
\text { on inventory and trend analysis }\end{array}$ & $\begin{array}{l}\square \text { The takeback system is interesting. However, } \\
\text { suppliers should be the ones responsible of the } \\
\text { management of such systems. } \\
\square \text { The university should participate in takeback } \\
\text { systems at some point but we do not see the } \\
\text { value right now. It is a matter of prioritising } \\
\text { more relevant actions }\end{array}$ & $\begin{array}{l}\text { The university receives so many products } \\
\text { by so many different suppliers that it would } \\
\text { be very difficult to map delivery points and } \\
\text { analyse logistic requirements. } \\
\text { Lab waste is very difficult to be managed } \\
\text { through takeback systems due to legal } \\
\text { concerns (e.g. contamination criteria). It } \\
\text { may be difficult to find suppliers interested } \\
\text { in managing lab waste }\end{array}$ \\
\hline & $\begin{array}{l}\text { Cirkle }^{c} \\
\text { (Household } \\
\text { waste) }\end{array}$ & $\begin{array}{l}\text { Delivery of } \\
\text { seasonal produce } \\
\text { with a return } \\
\text { logistics service } \\
\text { for the collection } \\
\text { of household } \\
\text { reusable and } \\
\text { recyclable } \\
\text { products }\end{array}$ & $\begin{array}{ll}\circ & \text { Cirkle collects over } 20 \text { waste streams from their } \\
\text { customers } \\
\circ \text { Reusable products are sent to charities } \\
\circ \text { Recyclable materials are sent to recyclers } \\
\circ \text { Appeal by customers lie in the types of materials } \\
\text { collected, which include items that cause confusion, } \\
\text { frustration and inconvenience when it comes to } \\
\text { household disposal } \\
\circ \text { Materials: batteries, electronic waste, printer } \\
\text { cartridges, water filters, light bulbs and coffee } \\
\text { capsules, etc. }\end{array}$ & $\begin{array}{l}\square \text { The example is good but staff does not think it } \\
\text { is applicable in the university context because } \\
\text { the list of wastes collected by Cirkle probably } \\
\text { does not includes mattresses and other } \\
\text { problematic residential waste (e.g. wastes with } \\
\text { very low market value). } \\
\square \text { The university has a partner who delivers a kind } \\
\text { of a service like this in the canteens. } \\
\square \text { A very good area for exploration would be the } \\
\text { implementation of a return system for plastic } \\
\text { and glass bottles. It could have high application } \\
\text { in residences. }\end{array}$ & $\begin{array}{l}\text { The most problematic wastes for the } \\
\text { university are polystyrene (food purchase), } \\
\text { plastics (especially bags), mattresses and } \\
\text { similar wastes. These wastes are not } \\
\text { collected through takeback systems. } \\
\text { Polystyrene is light-weight, voluminous } \\
\text { and difficult to reuse or recycle. } \\
\text { The university needs to manage waste } \\
\text { streams that are not derived from campus } \\
\text { operations but generated by people who } \\
\text { brought different materials from households } \\
\text { (e.g. toothpaste tubes). } \\
\text { ॠind the right way to change people's minds } \\
\text { and behaviour through proper education. }\end{array}$ \\
\hline & $\begin{array}{l}\text { Desso and } \\
\text { Interface a } \\
\text { (Flooring } \\
\text { materials) }\end{array}$ & $\begin{array}{l}\text { Reutilisation and } \\
\text { recycling of of } \\
\text { modular carpet } \\
\text { tiles with } \\
\text { recycled-content }\end{array}$ & $\begin{array}{ll} & \text { Leasing schemes and take-back programmes } \\
\circ & \text { Modular tiles with recyclable yarn that can be } \\
\text { separated from the backing for reuse } \\
\circ \text { Cleaning, redesign, reuse and recycling }\end{array}$ & $\begin{array}{l}\square \text { The university already works with Desso in } \\
\text { some refurbishment activities with the purpose } \\
\text { of reusing carpets in closed-loop systems }\end{array}$ & $\begin{array}{l}\text { Find case studies showing the utilisation of } \\
\text { waste materials in construction projects }\end{array}$ \\
\hline
\end{tabular}

${ }^{\mathrm{a} E M F}$ (2017); ${ }^{\mathrm{H} H P}$ (2017); ${ }^{\mathrm{C} C i r c l e ~ E c o n o m y ~(2017) ; ~}{ }^{\mathrm{d}}$ Arup (2016); ${ }^{\mathrm{e} U n i v e r s i t y ~ w e b s i t e ; ~}{ }^{\mathrm{D}} \mathrm{DELL}$ (2017). 


\section{References}

Arup, 2016. The Circular Economy in the Built Environment. London, UK.

Circle Economy, 2017. Circular economy reports and insights. Circle Economy. https://www.circle-economy.com/.

DELL, 2017.2 Dell and the circular economy. https://www.dell.com/learn/us/en/uscorp1/corp-comm/circular-economy. Accessed: September 2017.

EMF, 2017. Circular economy case studies. Ellen MacArthur Foundation (EMF). https://www.ellenmacarthurfoundation.org/case-studies.

HP, 2017. HP Devise as a service (DaaS). https://www8.hp.com/h20195/v2/getpdf.aspx/4AA6-5363ENW.pdf._Accessed September 2017

Mendoza, J.M.F., Gallego-Schmid, A., Azapagic, A., 2018. Exploring the implementation of circular economy thinking in sustainability management systems by higher education institutions. Journal of Cleaner Production.

NETpositive Futures 2017. NETpositive Supplier Engagement Tool (HE). http://netpositivefutures.co.uk/netpositive-supplier-engagement/.

UoM, 2012. Campus Masterplan 2012-2022. The University of Manchester (UoM). http://documents.manchester.ac.uk/display.aspx?DoclD=15305.

UoM, 2017. Sustainable Resources Plan: supporting the responsible use of natural resources and materials. The University of Manchester (UoM). http://documents.manchester.ac.uk/display.aspx?DoclD=33195. 